
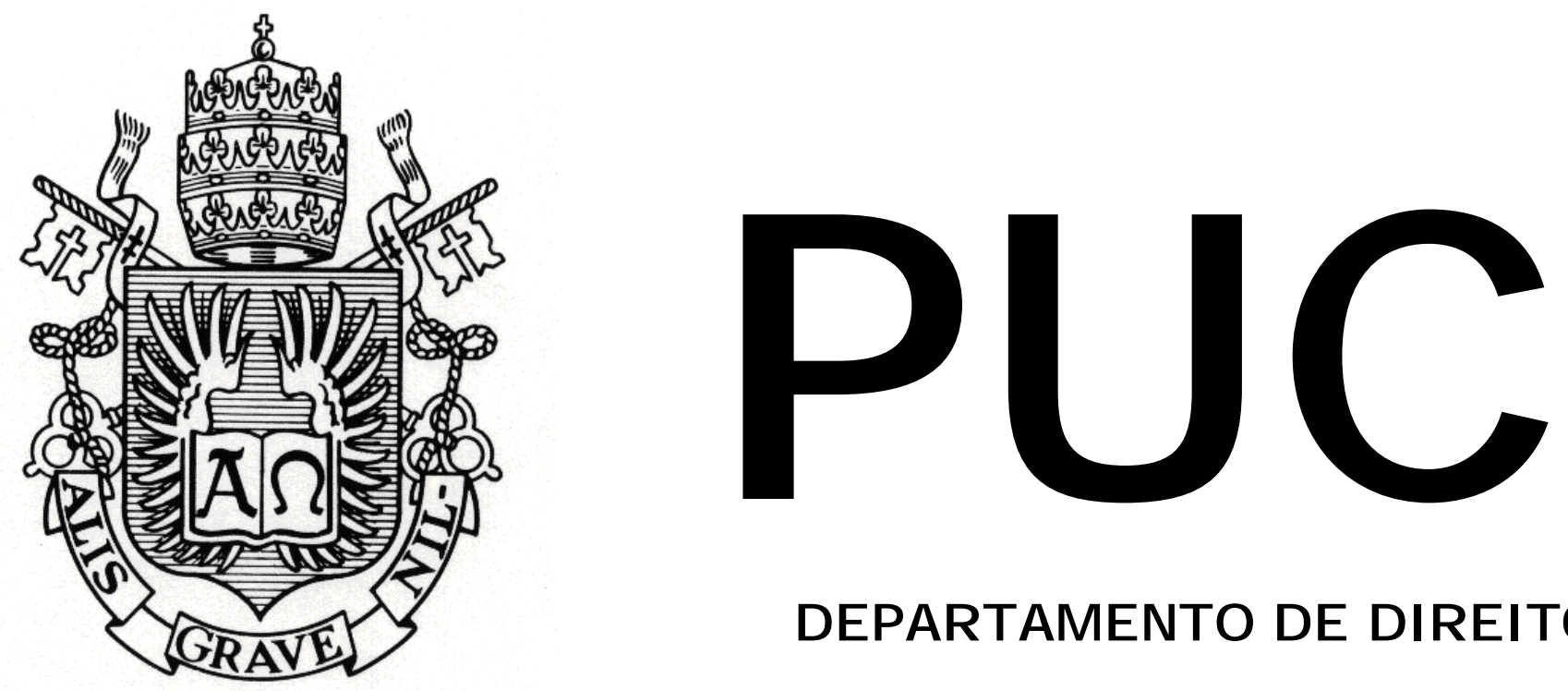

DEPARTAMENTO DE DIREITO

\title{
Considerações Sobre o Papel da Mídia no Processo Penal
}

por

Arianne Câmara Nery

ORIENTADOR(A): Prof ${ }^{a}$. Victoria de Sulocki

2010.2

PONTIFÍCIA UNIVERSIDADE CATÓLICA DO RIO DE JANEIRO

RUA MARQUÊS DE SÃO VICENTE, 225 - CEP 22453-900

RIO DE JANEIRO - BRASIL 


\title{
Considerações Sobre o Papel da Midia no Processo Penal
}

\author{
por \\ Arianne Câmara Nery
}

Monografia apresentada ao

Departamento de Direito da Pontifícia Universidade Católica do Rio de Janeiro (PUC-Rio) para a obtenção do Título de Bacharel em Direito.

Orientador(a): Prof ${ }^{\mathrm{a}}$. Victoria de Sulocki 
Aos meus pais, por estarem sempre ao meu lado, nesta minha longa caminhada pelo crescimento acadêmico e profissional. 
Agradeço:

Aos meus pais Elinaldo Ribeiro Nery e Maria Helena P. C. Nery,

Por serem o meu maior exemplo de superação e amor.

Aos meus amigos de sempre Vitor e Ana Lidia,

Pelo apoio incondicional de sempre.
À minha professora orientadora Victoria Sulocki,
Por ser um exemplo de profissional, e por tudo o que aprendi em sala de aula. 


\section{RESUMO}

Este trabalho tem como intuito abordar os principais aspectos do papel exercido pela mídia na sociedade, especificamente no que tange ao direito processual penal, analisando a relação entre a mídia e o Poder Judiciário como instituições do regime democrático.

É feita uma breve análise da evolução histórica das noções de opinião pública e imprensa, bem como dos diversos aspectos da atividade jornalística, com uma exposição da função da ética como cerne desta atividade. Em seguida, é feita uma análise acerca da colisão dos direitos fundamentais da liberdade de expressão e do direito a um julgamento criminal justo, com a exposição de caso em que as autoridades judiciárias, não atentando para a importância da efetiva ponderação de princípios, cometeram equívocos e até eventuais injustiças.

Por fim, são expostas algumas possibilidades e propostas para que possa ser garantido um julgamento criminal justo, sem o cerceamento de outros direitos fundamentais, tal como o direito à liberdade de expressão.

\section{PALAVRAS-CHAVE}

Mídia e Poder Judiciário

Processo penal

Julgamento criminal justo

Liberdade de expressão

Colisão de Direitos fundamentais

Ética no jornalismo 


\section{Sumário}

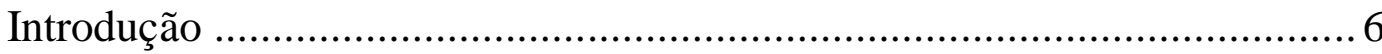

Capítulo 1. A relação institucional entre a mídia e o Poder Judiciário ..........9

Capítulo 2. Evolução histórica da noção de opinião pública e imprensa .... 20

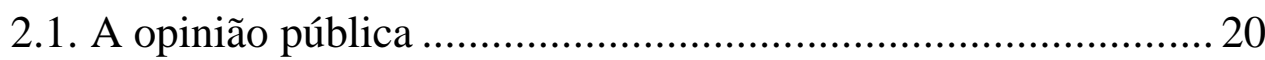

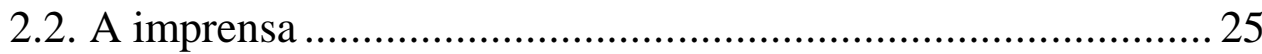

Capítulo 3. Aspectos da atividade jornalística e sua história........................ 26

Capítulo 4. A ética como cerne da atividade jornalística ............................. 32

4.1. Breve análise sobre a importância da responsabilidade

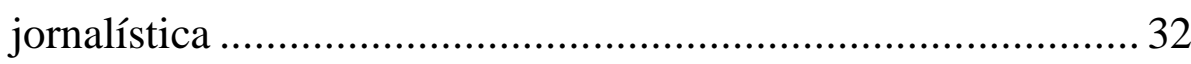

4.2. A recém revogada Lei de imprensa - Lei 5250/67 .................... 34

4.3. A necessidade dos limites éticos ................................................ 38

Capítulo 5. A imagem da violência e a construção social da criminalidade41

5.1. A política criminal sob a influência da mídia ............................. 41

5.2. Mídia e poder na Democracia ..................................................... 49

Capítulo 6. A colisão de direitos fundamentais: liberdade de expressão e informação X direito a um julgamento criminal justo ......................... 56

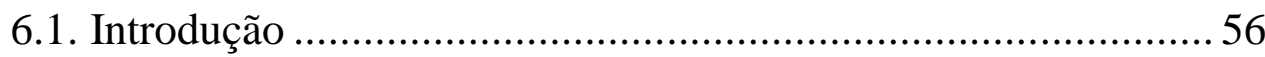

6.2. Liberdade de Expressão X Direito a um julgamento criminal

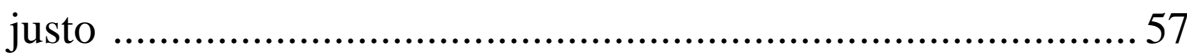

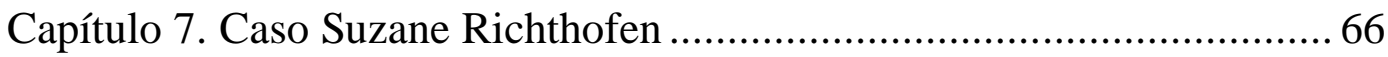

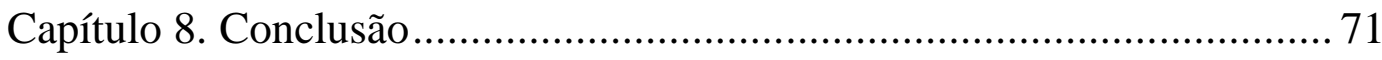

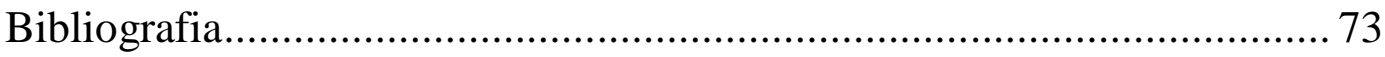




\section{INTRODUÇÃO}

É notoriamente conhecida a crescente influência que os órgãos da mídia exercem na vida cotidiana, decorrente de uma construção e solidificação da instituição ao longo de anos. Como conseqüência, é necessário reconhecer a ingerência de tais órgãos no trâmite justo e correto do processo penal, através da pressão da opinião pública. E na medida em que a distorção engendrada por alguns desses órgãos, para manipular a opinião pública, se estende ao órgão jurisdicional competente para o julgamento de causas penais, atingindo-lhe em seu livre convencimento, então se verificam intoleráveis distorções ocorridas durante o trâmite do processo penal.

A mídia, como instituição a ser estudada neste trabalho, pode ser definida como "meios de comunicação social de massa", no sentido de corporação jornalística e responsável pelos órgãos da mídia. O termo "órgãos da mídia", por sua vez, ressalta ainda mais o caráter múltiplo dos meios: rádio, cinema, televisão, livros, revistas, boletins, jornais, computador, etc.

É evidente que a mídia pode e deve desempenhar um importante papel no desenvolvimento de uma democracia plena e saudável. Todavia, não se podem esquecer os eventuais abusos, excessos de irresponsabilidade e falta de limite ético que circundam a atividade jornalística diariamente, sobretudo no que diz respeito às noticias oriundas do meio jurídico, especialmente em sua vertente penal.

A escolha do sensacionalismo como meio de expor ao máximo esse tipo de notícia demonstra, ainda, que parte da elite dirigente da corporação jornalística se curva ao objetivo empresarial da obtenção máxima de lucros, contrariando o principal objetivo originário da instituição, qual seja, o de se preocupar com o serviço público que deveria prestar à população. 
E assim a mídia, ao contrário do que dela se espera, presta um enorme desserviço à sociedade, seja impingindo-lhe a sensação, muitas vezes absurdamente exagerada de medo, pânico e insegurança, seja destacando superficialmente algumas das diversas mazelas do Poder Judiciário como causa do aumento da criminalidade - quando divulga, por exemplo, a morosidade e a impunidade em razão de decisões criticadas sem qualquer tipo de fundamento jurídico válido. Ou ainda criando, estimulando, mantendo e recriando verdades parciais que induzem campanhas que desembocam em reivindicações de reformas legislativas que, sabidamente, são de efeito meramente simbólico e sem qualquer eficácia. O resultado prático é evidente: desinformação e confusão do público consumidor, que passa a aceitar e a reproduzir as opiniões difundidas pelos órgãos da mídia.

Há que se reconhecer, no entanto, o esforço conjunto de ambas as corporações profissionais que vem sendo promovido nos últimos anos, no sentido de colocar os profissionais dessas áreas juntos para discutir a situação. Apenas com a colaboração efetiva destas duas importantes instituições será possível alcançar o desejável desenvolvimento democrático do país, embora, para isso, seja indispensável a colaboração engajada dos órgãos da mídia, na medida em que devem colocar acima de seus interesses empresariais as finalidades que lhes cabem no exercício de sua função.

Por fim, é a partir da análise do conflito de dois direitos fundamentais do Estado Democrático de Direito - a liberdade de expressão e informação e o direito a um julgamento criminal justo, que podemos desenvolver uma solução juridicamente aceitável para o problema, de forma paralela à conscientização das instituições de suas funções sociais.

Ambos os direitos constituem, juntamente com outros valores, o próprio núcleo de legitimidade do estado brasileiro, organizado sob a forma de um Estado de Direito, democrático e republicano, herdeiro que se pretende dos ideais de liberdade, igualdade e fraternidade do movimento 
iluminista. Isto porque, se é patente que não se pode permitir a perda da serenidade no julgamento do indivíduo, parece igualmente obvio que não se pode proibir, a priori, toda e qualquer divulgação de notícias sobre julgamentos criminais, já que ocorria o efeito oposto, que é a afetação do valor "liberdade de expressão e informação".

Deve, portanto, haver uma busca constante do meio jurídico, especialmente do Poder Judiciário, para se construir parâmetros específicos para solucionar tal colisão dentro do sistema jurídico brasileiro, iluminado pela teoria dos princípios. Para tanto, são essenciais as colaborações de doutrinadores, tais como Ronald Dworkin e Robert Alexy, cada vez mais lidos e estudados, cujas abordagens suscitaram uma enorme produção teórica nacional e internacional, que têm sido capazes de modificar de maneira radical a forma pela qual as decisões judiciais são construídas pelos tribunais e a forma como o direito é pensado pelos juristas. 


\section{Capítulo 1.}

\section{A relação institucional entre a mídia e o Poder Judiciário}

A mídia e o Poder judiciário são instituições imprescindíveis ao bom funcionamento da Democracia, e sua relação pode ser variada, na medida em que se alteram seus pontos de aproximação e distanciamento. Tal relação deveria fluir de acordo com o interesse maior que ambas têm como finalidade de suas atividades: o aprimoramento da consciência cívica e do processo democrático. Bastaria que a atividade por elas desempenhada fosse coordenada e comprometida com este fim, embora na prática outros interesses (econômicos, por exemplo), acabem sobrepostos na lógica de funcionamento institucional, sendo a satisfação do interesse social relegada a planos secundários e subordinados.

A mídia influencia outros planos, além do Poder Judiciário, englobando a compreensão que a própria sociedade, como entidade civil, tem de si e das instituições que a cercam. Ela eventualmente extrapola suas funções e assume outras que não lhe são legítima e legalmente reservadas.

A distância existente entre a realidade do homem comum e do Poder Judiciário é inegável, sendo esta a principal conseqüência da generalizada falta de cultura jurídica da sociedade brasileira, incluindo-se aí os profissionais do jornalismo, salvo raras exceções. A partir desta lacuna a mídia paulatinamente passou a assumir tarefas inerentes exclusivamente à função judiciária.

De acordo com Sylvia Moretzsohn, "o reconhecimento do papel político do jornalismo obviamente não lhe confere o direito de substituir outras instituições. Apesar disso, é notório que há temas como a hierarquia da sua importância e prioridade; para outros, não é possível afirmar que 
imprensa vem procurando exercer funções que ultrapassam de longe o seu dever fundamental, assumindo freqüentemente tarefas que caberiam à polícia ou à justiça". Ocorre que, "tal invasão busca legitimar a imprensa junto à opinião pública que ela mesma ajuda a formar, com a vantagem de atuar num reconhecido vácuo (a distância entre o aparelho judiciário e o homem comum, para ficar apenas no exemplo mais recorrente") ${ }^{1}$.

A mídia, portanto, acaba buscando a legitimação junto à sociedade enfraquecendo a imagem que ela tem do Poder Judiciário, o qual, muitas vezes, deixa lacunas de atuação preenchidas pela mídia, gerando um ciclo vicioso. A forma e instrumentos pelos quais a mídia conduz a sua atuação são diversos: na medida em que os órgãos divulgam o que bem entendem, selecionando, hierarquizando e divulgando as notícias, torna-se fácil legitimar-se junto à sociedade, influir em sua capacidade valorativa, manipular a opinião pública e distorcer os dados do processo judicial, por exemplo.

A mediatização da justiça como fenômeno de massa comporta diversos riscos, tais como as alterações de conduta por parte de agentes do processo, o desgaste profissional provocado pela sobreexposição, e a criação de estereótipos que insinuam ou estabelecem ligações entre o judicial e outros poderes ou interesses. Apesar disso, o conceito de separação e independência da justiça inclui sua capacidade de ser incólume e inerte a pressões e de preservar seu tempo e seus métodos.

Não se pode esquecer, além disso, conforme bem esclarece a juíza Salete Maccalóz, que:

\footnotetext{
"a atuação da imprensa também obedece à pressão do capital financeiro internacional, sua interferência e objetivos nos países emergentes. A ingerência econômica e política é muito antiga, exercida por todos os caminhos, mas os objetivos do neoliberalismo são responsáveis por grande parte das mudanças já acontecidas em qualquer instituição pública ou privada. São eles: liberalização
}

\footnotetext{
${ }^{1}$ MORETZSOHN, Sylvia; O caso 'Tim Lopes': O mito da 'mídia cidadã', p. 293).
} 
dos mercados de bens e capitais, desregulamentação acentuada da economia, privatização em massa e forte redução do papel do Estado"2.

Como a maioria da população age como leigo, devido à ausência de consciência crítica, falta de estudos, submissão ao pensamento das autoridades judiciárias, etc., não se consegue perceber o quanto este comportamento contribui para a extinção de um modelo de justiça que, apesar de imperfeito, perseguia a constituição de direitos individuais e sua salvaguarda. As próprias autoridades judiciárias muitas vezes também não se dão conta das consequiências diretas desse tipo de conduta.

Sendo assim, quando os meios de comunicação noticiam um caso, quase sempre se limitam a informar os fatos de forma a reproduzir a dialética do poder, muitas vezes com o elemento "sensacionalismo" para garantir maiores índices de vendagem. Mesmo quando os profissionais da mídia são egressos de seguimentos sociais mais baixos, não aproveitam a notícia para, no meio disso, exercer o seu papel político para, além de passar uma informação técnica, fazer uma análise crítica dos fatos. É o mau cumprimento do papel jornalístico, pois somado à falta de compromisso social, há ainda a distorção dos fatos e a omissão de dados importantes, com a premissa de que é isso o esperado pelo destinatário.

O que ocorre, na realidade, é o massacre do leitor/telespectador com notícias pré selecionadas por um editor/proprietário do meio de comunicação, que a repete tantas vezes até que sua absorção seja generalizada, ou como estratégia de ocupar o espaço de outras informações não tão interessantes para os que detém o poder de informar.

A verdade é que, novamente citando as palavras de Salete Maccalóz, "os meios de comunicação, como instrumentos da ideologia dominante, não se sentem responsáveis por nenhum conteúdo ou matéria capaz de dar às pessoas o discernimento e possibilidades de escolha. Se manipulam todos

\footnotetext{
${ }^{2}$ MACCALÓZ, Salete. O Poder Judiciário, os Meios de Comunicação e Opinião Pública, pp. 6566.
} 
os assuntos, porque seria diferente com a justiça? Para eles, cinema é cultura e justiça é a página policial, ou, no mínimo, personagem de seus próprios escândalos". 3

Os meios de comunicação, ao formarem a opinião pública, nada mais são do que os instrumentos mais eficazes de desconstituição da cidadania. Os Estados Unidos, por exemplo, perceptivelmente se utilizaram dos meios de comunicação como meio e forma de dominação para toda a América latina, a partir da II guerra mundial, especialmente através da televisão e da informação.

Desta forma, a sociedade tem representações antagônicas das instituições mídia e Poder Judiciário: os órgãos da mídia gozam de elevado grau de prestigio, enquanto o Poder Judiciário naufraga em meio ao descrédito e a desconfiança. Ressalte-se que não se busca aqui justificar o descrédito no judiciário tão somente com o papel da mídia, mas é importante ressaltar que uma das grandes conseqüências do mau uso deste poder é o agravo da situação enfrentada pelo corpo jurídico no Brasil.

A situação piora ainda mais quando se trata da aplicação da lei penal. Há nitidamente uma pressão externa, concebida porque a comunicação social se intrometeu no discurso jurídico-penal de tal maneira que o ponto central, hoje, deixou de ser a compreensão de dois sistemas - a justiça penal e a comunicação social -, operando paralelamente. Pelo contrário - há uma aceitação de que a comunicação social se intrometeu na discursividade penal. E a partir disto, a crise da justiça penal, decorrente da abertura forçada ou consentida à comunicação social, é e continuará sendo uma inesgotável fonte de perplexidades e de irritações hermenêuticas, até que, de alguma forma, o poder de fato da comunicação social passe a ser democraticamente legitimado, responsabilizado.

\footnotetext{
${ }^{3}$ MACCALÓZ, Salete; O Poder Judiciário, os Meios de Comunicação e Opinião Pública, pp. 183184.
} 
Uma questão intimamente relacionada a esta é como se dá o relato da atividade judicial pela mídia. É desta forma que a mídia participa diretamente na efetivação de um objetivo processual, que é a publicidade, inclusive amplificando a divulgação de atos públicos do processo. $\mathrm{O}$ efeito negativo, no entanto, é que a sociedade deveria possuir uma necessária compreensão do que é a atividade dos jornalistas, sobretudo quando estes cometem atos de desobediência e violam o segredo de justiça e das fontes, por exemplo. É evidente que a ampla publicidade do processo deve ser regra, em relação à sua finalidade jurídica - mas quando o caso é acompanhado pelos órgãos da mídia, a publicidade é ampliada, saindo do âmbito dos sujeitos do processo, para reverberar no seio social como um todo.

Em função disso o segredo de justiça eventualmente torna-se necessário ao trâmite de certos processos, embora os órgãos da mídia possam se utilizar de outros meios para tornar possível a descoberta de fatos inicialmente protegidos pelo sigilo. Conseqüentemente, a mediatização do processo leva ao efeito da aparente credibilidade dos fatos divulgados. De acordo com José Narciso da Cunha Rodrigues:

"paradoxalmente a evolução do direito criminal e a mediatização do processo criaram condições para que a questão do segredo de justiça fosse resposta e maximalizada ao arrepio do seu contexto histórico e cultural: o direito criminal, porque definiu novos tipos de criminalidade (designadamente no domínio político, econômico, financeiro e informático) que vieram agudizar o relevo e a frequiência dos chamados crimes de colarinho branco; a mediatização, porque, numa criminalidade com elevado valor/notícia, o processo produz um efeito de credibilização dos factos e de estigmatização que torna particularmente tensa a relação entre a justiça e as pessoas envolvidas". Então, "esta situação é das que mais intensamente reflecte a interacção entre justiça e media".

Os atores do processo e os interessados na causa acabam tornando-se também personagens no palco da mídia, cujos focos são a sustentação e defesa de seus direitos perante o órgão jurisdicional competente e a

\footnotetext{
${ }^{4}$ RODRIGUES, J. N. Cunha. Justiça e Comunicação Social: mediação e interação, revista Portuguesa de Ciência Criminal, Coimbra, Coimbra Editora, ano 7, Fascículo 4. ${ }^{\circ}$, out.-dez. 1997, pp. 531-576.
} 
amplificação do impacto dos fatos que sustentam a defesa de seus interesses perante a opinião pública. Trata-se do "aproveitamento que a investigação

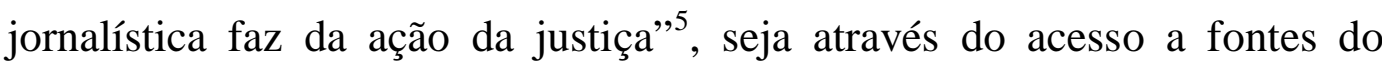
processo, seja em contato direto com os sujeitos processuais. A relação entre a investigação jornalística e a investigação judiciária gera diversos equívocos, especialmente quando torna suas fronteiras tênues e dificilmente compreensíveis para o público, e lança uma suspeição sobre os operadores judiciais acerca da existência de "fugas de informação" e quanto às eventuais motivações que lhe originam.

A suspeição é geralmente difundida (i) ou por pessoas ou grupos emprenhados na perseguição dos argüidos; ou (ii) é induzida pelos próprios argüidos ou por interesses com eles identificados, com dois principais objetivos: desacreditarem a ação da justiça, insinuando sua parcialidade ou seu escapismo a regras processuais e deontológicas; e para vitimizarem-se, tirando os créditos dos fatos ou retirando a culpa de seus autores.

O Ministro Sálvio de Figueiredo Teixeira expõe como algumas das principais mazelas em relação ao Poder Judiciário a impunidade, o formalismo exacerbado, o nepotismo, a morosidade e o corporativismo; em relação à imprensa, aquelas decorrentes de abuso e irresponsabilidade ${ }^{6}$. Vemos diariamente exemplos destas mazelas, que podem ser encontradas nos principais veículos de notícias do Brasil a depender de conjunções políticas, debates legislativos no Congresso Nacional, pressões oriundas de motivações variáveis e mobilização da sociedade civil, o que influirá diretamente no intervalo de tempo que permanecerão na pauta da mídia.

A respeito dos problemas relacionados à atividade desempenhada pelos jornalistas, pode-se destacar o abuso, excesso e irresponsabilidade

\footnotetext{
${ }^{5}$ RODRIGUES, J. N. Cunha. Justiça e Comunicação Social: mediação e interação, revista Portuguesa de Ciência Criminal, Coimbra, Coimbra Editora, ano 7, Fascículo 4. ${ }^{\circ}$, out.-dez. 1997, pp. 557.

${ }^{6}$ TEIXEIRA, Sálvio de Figueiredo. A imprensa e o Judiciário. Revista do Instituto de Pesquisas e Estudos - Divisão Jurídica. Bauru: Instituição Toledo de Ensino, n. ${ }^{\text {1 }}$ 15, pp. 15-20, ago.-nov. 1996; Justitia, São Paulo, n. ${ }^{\circ} 58$ (175), pp. 34-37, jul.-set. 1996.
} 
com o qual os profissionais dos órgãos da mídia divulgam notícias envolvendo crimes, criminosos e processos penais. A divulgação é quase sempre parcial e interessada, e a mídia acaba por destruir, em dias, reputações construídas durante anos, em troca de sensacionalismo e lucro, construindo no imaginário social o estereótipo do criminoso, o qual está geralmente relacionado aos integrantes das camadas mais populares da sociedade.

Salete Maccalóz enfatiza que "no papel que a mídia presta para os casos criminais há uma exploração estudada da família, amigos e local de atividades do incriminado, com o claro propósito de aproximar o seu modelo de vida ao da grande população, deixando subliminarmente a mensagem do que acontecerá a todos os que praticarem os mesmo ilícitos”.

A autora exemplifica, citando que "algumas tintas são muito bem escolhidas para o colorido especial quando trata de vítima da classe média ou abastada, como no caso de um porteiro de edifício que seqüestrou e matou uma moradora de zona sul, no Rio de Janeiro". Neste caso, sucedeu que "as reportagens a respeito induziram comportamentos ao ponto de fazer todos os porteiros culpados de alguma coisa". Em síntese, "os casos criminais, hoje apresentados pela imprensa, recebem o seguinte diagnostico: ela (a mídia) condena primeiro, para depois investigar, sem o empenho de redimir os seus erros flagrantes" ${ }^{7}$.

A sistemática processual adotada pelo Estado moderno tem como componente essencial a convicção, elemento subjetivo que se forma com o conhecimento, maturado nas fases de postulação e probante. Ou seja, a justiça efetiva se faz a partir da análise do que seria a melhor solução ou os melhores argumentos para a conclusão, uma vez que o processo é a pesquisa pela verdade.

\footnotetext{
${ }^{7}$ MACCALÓZ, Salete; O Poder Judiciário, os Meios de Comunicação e Opinião Pública, pp. 120.
} 
A mídia, de forma diametralmente oposta, vende a idéia de que a velocidade é sinônimo de qualidade, tornando sem importância a idéia de que a demora natural do processo - claro, garantindo-se que o processo tenha duração razoável - é elemento da tecnicidade processual, sendo sempre referida como um composto exagerado de recursos que sobrecarregam os tribunais. Ademais, acaba por confundir a tecnicidade necessária a um julgamento justo com a morosidade dos Tribunais, que, esta sim, deve ser combatida com todos os meios. E assim a mídia consegue alcançar seus dois objetivos: legitimar-se junto à sociedade e desqualificar o Poder Judiciário.

O enaltecimento da velocidade não é, portanto, apenas mais uma campanha de venda de um produto; é uma tarefa política, por meio da qual se condenam instituições, modelos, pessoas e coisas, sem qualquer reflexão prévia, debate ou conscientização.

O brasileiro deposita hoje, na imprensa, a esperança que não se concretiza no Poder Judiciário, de ver uma resposta rápida aos fatos. Assim, a denúncia impressa acaba sendo interpretada como a sentença que não foi dada, perdida no labirinto do processo. O povo, com a falta de punição jurídica, acaba se contentando com o escândalo jornalístico, e, com isso, informar passou a ser também uma forma de punição, a despeito do fato de que imprensa, definitivamente, não é sinônimo de justiça. O editor acaba por transformar a informação em uma forma de autoridade que não possui, acarretando acusações sem apuração, e colocando réus, sem defesa, na prisão da opinião pública.

Esse comportamento contraria a finalidade de cada uma dessas instituições, que se identificam claramente com a prestação de um serviço público: no caso da mídia, divulgar dados e informações através de notícias verdadeiras e isentas ao público consumidor; e no caso do Poder Judiciário, a solução dos conflitos de interesses representados pelas partes envolvidas na lide, ou seja, a prestação jurisdicional. 
Na prática, no entanto, a mídia, como empresa privada, tem como finalidade primordial a máxima obtenção de lucros, o que a diferencia consideravelmente de outros órgãos jurisdicionais que têm como função exclusiva a prestação do serviço público, essencial ao pleno exercício da Democracia. A verdade é que, apesar de inúmeros os pontos de divergência entre jornalistas e juristas, quem realmente é prejudicado nesta relação é o cidadão, que não dispõe de mecanismos eficazes de controle e fiscalização da qualidade do trabalho exercido pelos profissionais da imprensa, ficando sujeito apenas às impressões originadas com o que é escolhido para ser divulgado pela mídia.

A crítica que se faz, portanto, é a ambas as instituições. Se, por um lado, a corporação jurídica não se digna a se tornar mais acessível aos profissionais do jornalismo e, conseqüentemente, à sociedade, por outro lado a sociedade (e os jornalistas, principalmente) carece da mínima cultura jurídica necessária à compreensão dos assuntos jurídicos e ao trâmite dos processos judiciais. As razões para essa deficiência são as mais diversas, tais como o desinteresse pela vida pública no país, o desinteresse pela atividade desempenhada diariamente pelo Poder Judiciário, o analfabetismo, etc.

Rogério Schietti Machado Cruz, no texto A imprensa e as decisões judiciais, assevera que "uma das razões que contribuem para esse triste distanciamento - que se confunde com seus próprios efeitos e, por isso, engendram um círculo vicioso - reside na falta de cultura jurídica do povo brasileiro". Esclarece ainda que "falta de cultura jurídica não no sentido de que as pessoas leigas não têm o desejável tirocínio para entender os meandros, tecnicismos e termos próprios do Direito, o que realmente não têm. O brasileiro não tem o costume de interessar-se por assuntos relativos à função judiciária do Estado"».

\footnotetext{
${ }^{8}$ CRUZ, Rogério Schietti Machado. Publicidade e Sigilo no Processo Moderno. Doutrina. Vol. 9, Rio de Janeiro: Instituto de Direito, pp. 311-323, 2000.
} 
A estrutura do Poder Judiciário, embora esteja registrada na Constituição Federal, é sequer conhecida por boa parte dos jornalistas, que incidem em erros primários ao noticiar fatos que ocorrem no âmbito das atividades jurisdicionais. Assim, verifica-se que quando os jornalistas atuam em matérias que envolvem processos judiciais, especialmente os de natureza penal, eles falam ou escrevem sobre matéria cujos termos técnicos são a eles desconhecidos, cuja tramitação se dá em órgãos com peculiaridades específicas, e com eventos que para eles são inexplicáveis. Ainda se dirigem a um público que, da mesma forma, pouco sabe a respeito do assunto. Os equívocos neste tipo de comunicação são, portanto, inevitáveis e muito numerosos, seja na transmissão pelo jornalista, seja na recepção pelo consumidor.

Além disso, percebe-se o cunho "justiceiro" do qual se reveste o jornalismo sensacionalista, o que muitas vezes representa verdadeiras violações explícitas a direitos constitucionalmente assegurados ao suspeito investigado, tais como a intimidade, a vida privada, a honra, a imagem, num primeiro momento; e o devido processo legal, a paridade de armas entre as partes, a presunção de inocência, a imparcialidade do julgador, etc., num segundo momento. Veremos a questão dos princípios constitucionais mais adiante.

Fato é que esses princípios constitucionais são fruto de séculos de exploração, disputas de interesses e conquistas alcançadas, o que torna sua violação algo muito maior e mais grave do que parece numa primeira análise: não ofende somente o investigado, vítima direta; atinge a sociedade como um todo. Especialmente porque qualquer integrante do povo pode assumir o papel de investigado, a qualquer momento - é um risco geral, constante e iminente.

Com isso, os objetivos comerciais da atividade empresarial da mídia devem ser lembrados sempre, apesar disso não significar, necessariamente, que a qualidade do serviço prestado seja manipulada indiscriminadamente. 
Da mesma forma, para se tentar uma aproximação positiva entre a mídia e o Poder Judiciário, devem-se compreender as verdadeiras razões de sua demora na prestação jurisdicional, até o limite imposto pela razoabilidade, a importância do respeito aos direitos e garantias individuais e as indispensáveis imparcialidade e neutralidade, com as quais deve se comprometer o órgão prolator da decisão do caso sob julgamento. Seguidas estas regras, a aproximação entre estas duas instituições aproveitaria a todos. 


\section{Capítulo 2.}

\section{Evolução histórica das noções de opinião pública e imprensa}

\subsection{A opinião pública}

A formação de uma opinião pública em sentido estrito, de acordo com Habermas, ao se referir sobre a social-democracia ocidental instalada e desenvolvida nos principais países da Europa, "não é garantida efetivamente pelo fato de que qualquer um poderia expressar livremente a sua opinião e fundar um jornal". O pensador, ao discorrer sobre o assunto, cita Ridder, para quem a "liberdade pública de opinião, que primeiro providencia para os cidadãos a participação com igualdade de chances no processo de comunicação pública; de modo correspondente, ela complementa a clássica liberdade de imprensa das pessoas privadas através de uma obrigação institucional dos órgãos jornalísticos quanto ao ordenamento jurídico básico do Estado social-democrata”. Desta forma, "a liberdade de exprimir a opinião através da imprensa não pode mais ser considerada como parte das tradicionais manifestações de opinião dos indivíduos enquanto pessoas privadas" 9 .

Devido ao desenvolvimento da social-democracia ocidental o crescente pluralismo entre os interesses concorrentes dificultou o surgimento de um autêntico interesse geral, o que é um requisito essencial ao estabelecimento de uma opinião pública legítima. Desta forma, a função crítica da publicidade é relacionada à opinião pública verdadeira, enquanto que a função manipulativa da publicidade se relaciona com a opinião nãopública. Essas duas funções devem ser devidamente diferenciadas.

9 HABERMAS, Jurgen. Mudança Estrutural na Esfera Pública. Rio de Janeiro: Tempo Brasileiro.1984, pp. 264-265. 
A mera transmissão de uma mensagem de um emissor para um receptor, por si só, não equivale, necessariamente, à comunicação. A efetiva comunicação ocorre quando há uma real via de mão dupla - aí sim ocorre interlocução entre ambos, restando demonstrada a compreensão da mensagem transmitida, concordem ou não com ela.

Desta forma, Habermas cita dois caminhos para se definir o conceito de opinião pública. Expõe que "um conduz de volta a posições do liberalismo, que, em meio a uma esfera pública desintegrada, queria salvar a comunicação (...) num círculo interno de representantes capazes de serem no âmbito público os formuladores de opinião, um público pensante bem no meio do público apenas aclamativo". Alternativamente, "o outro caminho leva a um conceito de opinião pública que abstrai completamente critérios materiais como racionalidade e representação, limitando-se a critérios institucionais", diferencia o pensador. Em qualquer caso, "ambas as versões levam em conta o fato de que, no processo de formação de opinião e da vontade nas democracias de massas, a opinião do povo, independente das organizações através das quais ela passa a ser mobilizada e integrada, raramente ainda mantém algum função politicamente relevante" ${ }^{\text {" }}$.

Atualmente, o comportamento real do próprio público não se identifica mais com a noção de opinião pública. Este conceito só é considerado em relação à imposição subjetiva de um processo grupal correlacionado com a opinião dominante, evidente e previamente estabelecido. A opinião pública tornou-se, portanto, uma espécie de ficção constitucional, que não pode mais ser identificada no comportamento dos elementos sociais.

Habermas cita, ainda, que o grau de caráter público de uma opinião pode ser medido pelo seguinte critério: até que ponto a opinião provém da esfera pública interna à organização de um público constituído por

\footnotetext{
${ }^{10}$ HABERMAS, Jurgen. Mudança Estrutural na Esfera Pública. Rio de Janeiro: Tempo Brasileiro.1984, pp. 276-278.
} 
associados, e até que ponto a esfera pública interna à organização se comunica com uma esfera pública externa que se constitui no intercâmbio jornalístico-publicitário através dos jornalistas e entre organizações sociais e instituições estatais?

Se partirmos dessa análise, a conclusão é que não podemos mais encontrar uma esfera pública como a descrita inicialmente por Habermas a reunião de um público formado por pessoas privadas que constroem uma opinião pública com base na racionalidade do melhor argumento, e fora da influência do poder político e econômico, e da ação estratégica.

Torna-se necessário, portanto, nesse contexto, fazermos uma crítica ao processo de superficialização da política e do debate político, à inconsistência do que tem sido chamado de opinião pública, aos métodos quantitativos e qualitativos de apreensão desta opinião, à burocratização e mercadorização crescente do espaço público, à manipulação, e ao papel que mídia e marketing exercem neste sentido. No entanto, admite-se que os grandes meios de comunicação de massa, desde que democratizados e despidos da mera função de mercadoria, são instrumentos indispensáveis para a democratização da produção de opiniões públicas.

Fazendo um estudo etimológico do termo "opinião", os mais conceituados dicionários de língua portuguesa indicam que o significado do termo é: "1. Modo de ver, de pensar, de deliberar (...); 6. Filos. Atribuição do caráter de verdade ou falsidade a uma asserção sem que tal atribuição se faça acompanhar de certeza (...)"11. "1. Maneira de pensar, de ver, de julgar (...); 2. Julgamento pessoal (justo ou injusto, verdadeiro ou falso) que se tem sobre determinada questão (...); 8 fill crença adotada como verdade pelo senso comum sem qualquer reflexão a respeito de sua validade, de seus

\footnotetext{
${ }^{11}$ FERREIRA, Aurélio Buarque de Holanda. Novo Dicionário da Língua Portuguesa. Rio de Janeiro: Nova Fronteira, 2004, p. 1001.
} 
pressupostos e dos meios pelos quais foi obtida""12; "1. Maneira de opinar; modo de ver pessoal (...); 2. Asserção sem fundamento; presunção (...)"13.

Podemos, assim, concluir que a "opinião pública" seria o juízo coletivo adotado e exteriorizado no mesmo direcionamento por um grupo de pessoas com expressiva representatividade popular sobre algo de interesse geral. A opinião pública sofreu tal degeneração que ela hoje aceita passivamente qualquer notícia divulgada, num processo de consensualização e não de contestação.

Uma das explicações possíveis para a hegemonia da mídia é a incapacidade verificada pelas pessoas para processar as informações disponíveis, especialmente porque o consumidor não está preparado para tanto. Daí o consenso. Além disso, a abundância de informações é tamanha que até os próprios jornalistas provavelmente se vêem incapazes de processar tantas informações de maneira correta.

Fato é que os órgãos da mídia distanciaram-se de sua função inicial, de reportar e narrar os fatos, e começaram a se destacar como intervenientes e invasores dos fatos. Passaram, na realidade, a opinar, com o intuito de formar opinião. Nesse contexto a relação entre a mídia e a opinião pública chegou a um tamanho grau de hegemonia do primeiro e submissão do segundo que, atualmente, pode-se dizer que, a opinião pública reduziu-se à opinião publicada pelos órgãos da mídia.

Segundo o professor Geraldo Prado, "nos dias de hoje, porém, o controle empresarial dos meios de comunicação de massas, a lógica da competitividade e do mercado que orienta a atuação deles e a distorção da própria noção de publicidade, que, antes de incentivar a participação democrática da maioria das pessoas relativamente aos negócios da sua

\footnotetext{
${ }^{12}$ HOUAISS, Antônio. Dicionário Houaiss da Língua Portuguesa. Rio de Janeiro: Ed. Objetiva, 2001, p. 2071.

${ }_{13}$ MICHAELIS: Moderno dicionário da língua portuguesa. São Paulo: Cia. Melhoramentos, 1998, p. 1498.
} 
cidade e de seu país, anula essa participação, constroem uma nova realidade, paradoxalmente virtual ou espetacular" ${ }^{\prime 14}$.

Sendo assim, para que exista, a opinião pública exige um mínimo de autonomia, ou seja, um mínimo de informação, o próprio acesso à informação, o que pressupõe a existência de veículos independentes e isentos, de juízo crítico e de uma classe média educada, autônoma e que exerça a cidadania, ao invés de uma mera "sociedade de classes".

Segundo o autor Fábio Martins de Andrade, no contexto atual, em que essa autonomia em relação ao acesso à informação não ocorre efetivamente, "em vez de se ter expressões como meios de comunicação de massa ou órgãos de comunicação social, talvez fosse melhor sustentar denominação mais condizente com seu papel totalitário, uniforme e difusor do discurso político hegemônico, como por exemplo, 'órgão de imposição comunicativa para a massa'. Esta denominação explicita as principais características dos órgãos da mídia atualmente, ligadas às idéias de: totalitarismo, hegemonia, unilateralismo, descontrole e com imenso poder de imposição, influência e persuasão" ${ }^{\text {"15 }}$.

Por fim, é válido ressaltar que a real missão da imprensa, cuja importância é a de capacitar o cidadão para que ele possa formar sua própria opinião - é a de informar a sociedade, para que esta também esteja apta a formar uma verdadeira opinião pública. Somente assim os órgãos da mídia estarão contribuindo para o desenvolvimento pleno da democracia e para a crescente capacitação cívica do cidadão de formar sua própria opinião sobre os fatos e acontecimentos que o rodeiam, sendo, inclusive, a semente necessária para que a noção de opinião pública eventualmente recrudesça e retome o sentido que Habermas lhe aferiu quando a definiu em sua obra.

\footnotetext{
14 PRADO, Geraldo. Sistema Acusatório. A conformidade constitucional das leis processuais penais. Rio de Janeiro: Lumen Juris, 1999, p. 179.

${ }^{15}$ ANDRADE, Fábio Martins de. Mídia e Poder Judiciário - A Influência dos órgãos da mídia no processo penal brasileiro. Rio de Janeiro: Lumen Juris, 2007, p. 48.
} 


\subsection{A imprensa}

A historia da imprensa, por sua vez, começa com a descoberta da impressão, atribuída a Gutenberg, por volta do ano 1438. Sua evolução inscreve-se num fundo histórico que lhe determinou as orientações. Com isso, a afirmação de sua liberdade passa pela emergência do individualismo, pela restauração da liberdade religiosa, pelo reconhecimento da liberdade de opinião, pelos progressos da idéia de tolerância, por novas reflexões sobre o Estado e a sociedade, pelo aparecimento de uma esfera pública, entre a esfera privada dos indivíduos e a esfera do poder, por experiências individuais e coletivas, por acontecimentos sociais e políticos.

No fim do século XVIII a liberdade de imprensa passou a ser formada como conceito, reconhecida como princípio, admitida como um dos direitos fundamentais do homem. A liberdade de imprensa, portanto, é um dos aspectos da liberdade de expressão, que pertence a todos os homens. Não é, por isso, privilégio da imprensa, que dela reclama, ou dos homens cujo ofício é informar, formular opiniões ou emitir críticas.

De acordo com a professora Cecília Coimbra, "hoje, há aqueles que julgam a mídia como o grande inimigo e eterno vilão da história, como se todos estivéssemos à mercê de seu enorme poder. Há, diferentemente, que entendê-la, procurar suas gêneses e pensar em seus efeitos"16. Israel Drapkin Senderey escreveu ainda que, “infelizmente a imprensa não 'é' o que 'deveria ser'. Das opiniões que são emitidas sobre o que a imprensa 'deveria ser', a maioria provém de pessoas que ignoram realmente o que a imprensa 'é",17.

\footnotetext{
${ }^{16}$ COIMBRA, Cecília. Operação Rio: o mito das classes perigosas. Rio de Janeiro: Oficina do Autor/Intertexto, 2001, p. 74.

${ }^{17}$ SENDEREY, Israel Drapkin. Imprensa e Criminalidade, p. 19.
} 


\section{Capítulo 3.}

\section{Aspectos da atividade jornalística e sua história}

Sem dúvida, um dos principais problemas da imprensa atualmente é o abandono da nobre função dos órgãos da mídia, que é o de divulgar corretamente as notícias, baseando-se em informações verificadas e comprovadas, face à enorme influência do poder de que dispõe a minoritária classe dominante.

No caso do Brasil, a situação se agravou com o autoritarismo imposto no regime militar, em 1964, que chegou a ridicularizar a função da imprensa brasileira, com a utilização de órgãos militares "competentes" dedicados à filtragem e divulgação controlada de notícias através da censura, reduzindo radicalmente a função criativa e investigativa do jornalismo.

No entanto, apesar do quadro atual de mercantilizarão da atividade jornalística, isto não retira o fundamento da razão de ser da imprensa: o direito à informação dos cidadãos. A partir deste direito fundamental, surge o debate público que, conjugado com o exercício ético do jornalismo, leva à sedimentação do bom jornalismo e, conseqüentemente, do desenvolvimento pleno da Democracia.

Eugênio Bucci alerta que “jornais, revistas, emissoras de rádio e televisão dedicados ao jornalismo, assim como os sites informativos na internet, nada disso deve existir com a simples finalidade de gerar empregos, fortunas e erguer os impérios da mídia". Ao contrário, "deve existir porque os cidadãos têm o direito à informação". Entretanto, "sem que esse direito seja atendido, a democracia não funciona, uma vez que o debate público pelo qual se formam as opiniões entre os cidadãos se torna um debate viciado. Por isso a imprensa precisa ser forte, independente e 
atuante", explica o autor. Daí a conseqüência: "é verdade que a atividade jornalística se converteu num mercado, mas, atenção, esse mercado é conseqüência, e não o fundamento da razão de ser da imprensa". E desta forma, "do direito fundamental a que corresponde a imprensa, o direito à informação, resulta a ética que deveria reger os jornalistas e as empresas de comunicação (...)". O autor adverte ainda que "quando o poder age no sentido de subtrair ao cidadão a informação que lhe é devida, está corroendo as bases do exercício do jornalismo ético, que é o bom jornalismo, e corrompendo a sociedade" $" 18$.

Há uma necessidade constante de resguardar a independência editorial do órgão da mídia de influências e pressões externas ao seu funcionamento. Impõe-se ressaltar um dos maiores problemas verificados: o regime de pressa no jornalismo "em tempo real". A abundância de notícias oferecidas pelos órgãos da mídia, impelidos pela urgência e expectativa de destaque em relação aos concorrentes, é a cegueira do público pelo excesso de informações recebidas. Como resultado, os diversos órgãos da mídia se complementam na sequiência da divulgação de suas notícias, privilegiando a redundância do repetido, a produção do consenso generalizado e da unanimidade.

Somado a esse problema, há também a questão da preferência da pauta dos órgãos da mídia para os assuntos mais vendáveis, para superação da concorrência. Juntando os elementos "concorrência", "pressa" e "sensacionalismo", então dificilmente a divulgação da notícia alcançará o necessário equilíbrio de reflexão e pesquisa. A informação, especialmente a televisada, tornou-se essencialmente um espetáculo, e em função disso ela se nutre fundamentalmente de sangue, de violência e de mortes.

Tais problemas contrariam o conceito de ética jornalística que, de acordo com diversos profissionais da área, seria baseada na busca pela verdade dos fatos. Claro que a busca pela verdade é, na realidade,

${ }^{18}$ BUCCI, Eugênio. Sobre Ética e Imprensa. São Paulo: Companhia das Letras, 2000, p. 33. 
intangível, motivo pelo qual se aceita como verdadeira apenas uma versão dos fatos que, quando relatado, possui alto teor ideológico entranhado. A imprensa nada mais é, portanto, do que a tradução de uma real relação de confiança, e não simplesmente um serviço de fornecimento de produtos informativos para o consumo.

O relato jornalístico deve guardar o mínimo de confiabilidade, um mínimo sem o qual a autoridade da imprensa está perdida, apesar de a verdade da imprensa ser uma verdade "precária", pois jamais virá com a veracidade total. Assim, se a verdade é precária, então a credibilidade da imprensa pode ser duradoura, já que ela depende apenas do vínculo de confiança.

O jornalista Ignacio Ramonet esclarece, neste sentido, que "no nosso ambiente intelectual, a verdade que conta é a verdade midiática. Qual é essa verdade?" Ora, "se, a propósito de um acontecimento, a imprensa, o rádio e a televisão dizem que alguma coisa é verdadeira, será estabelecido que aquilo é verdadeiro. Mesmo que seja falso. Porque a partir de agora é verdadeiro o que o conjunto da mídia acredita como tal”. Por outro lado, “o único meio de que dispõe um cidadão para verificar se uma informação é verdadeira é confrontar os discursos dos diferentes meios de comunicação. Então, se todos afirmam a mesma coisa, não resta mais do que admitir esse discurso único..."19.

Para haver um jornalismo que garantisse aos sujeitos nela expostos a efetivação dos direitos constitucionalmente garantidos, num contexto em que a verdade exibida pelos órgãos da mídia é sempre relativa e apenas chega ao máximo de tangenciar a imparcialidade, seria necessário, por exemplo, publicar a versão da parte acusada com destaque proporcional à da acusação. Do contrário compromete-se a necessária "igualdade de posições e paridade de armas" entre as partes envolvidas na lide penal.

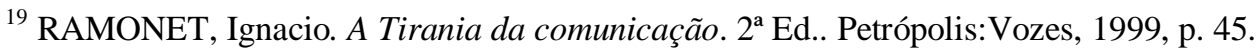


Isto seria necessário já que a notícia, como objeto de trabalho de um jornalista, é apenas um aspecto, um fragmento de realidade. E diante disso a informação oferecida é necessariamente fragmentária, parcial.

Entendido este caráter fragmentário das notícias divulgadas, a professora Sylvia Moretzsohn aduz outra perspectiva a respeito do assunto: “daí que o problema não é a fragmentação, mas as maneiras pelas quais esses fragmentos são reunidos". É que, "não raro se pretende estabelecer entre esses fragmentos um nexo que reforça o nonsense e provoca aquilo que em análise de discurso se define como 'efeito de apagamento', ocultando a materialidade do fato noticiado". Em conseqüência, "tudo se nivela, como se tivesse a mesma importância". Ocorre que, "esta não é, certamente, a única forma de apresentar a 'cultura em mosaico': há outras maneiras de ordenar a informação, dependentes, é claro, de outros critérios editoriais e éticos". A professora ressalta, por fim, que "é preciso lembrar o trabalho de interpretação que o próprio leitor é capaz de fazer, conforme seu nível de informação, sua condição cultural e uma série de outros fatores”20 .

Outro fator importante a ser lembrado é que, no jornalismo, tanto a palavra quanto o silêncio são colocados no mesmo plano, já que as consequiências de ambos alteram o sentido da verdade a qual o público tem o direito de conhecer. Através do que foi dito é sempre possível se chegar ao não dito, cujas pressuposições e implicitações estão contidas de forma velada ou camuflada em qualquer discurso.

Toda enunciação explícita é passível de discussões, tornando tudo o que seja dito passível de contradição. A imparcialidade, a objetividade e a veracidade da informação perseguidas pelo jornalista e apregoadas pelos veículos de informação são, na realidade, um mito. É que o conceito de objetividade consiste basicamente em descrever os fatos tal como aparecem, sendo um abandono consciente de interpretações para se extrair apenas o que se evidencia. E embora a competência funcional do jornalista

\footnotetext{
${ }^{20}$ MORETZSOHN, Sylvia. A ética jornalística no mundo ao avesso, pp. 318-320.
} 
seja avaliada pelo primor da observação exata e minuciosa dos acontecimentos do dia-a-dia, ao privilegiar aparências e reordená-las num texto, incluindo algumas e suprimindo outras, o jornalista acaba interferindo, inevitavelmente, nos fatores subjetivos. Com isso, a versão do fato sempre estará no lugar do fato.

Acerca deste tópico, o autor Antonio Francisco de Freitas esclarece que "o sentido do discurso, em muitos casos, está no não dito, ou seja, nas entrelinhas, nos pressupostos e subentendidos. No que não foi divulgado ou no que está implícito nas matérias jornalísticas". Segundo a ótica do autor, "nem tudo pode ser falado, nem tudo é falado, muitas coisas não podem ser ditas e muitas vezes se faz o contrário do que se diz". Ocorre que, "a verdade ou a real intenção do sujeito não é explicitada, pois vai contra os interesses, os desejos e a ideologia dominante, razão pela qual sempre se deve ter em mente, frente a qualquer discurso, a presença da subjetividade e dos processos de exclusão" 21 .

Atualmente, a mídia pode ser vista como um "quarto poder" da república, uma vez que não há dúvidas da influência da "boa" mídia no pleno processo democrático e de aprimoramento cívico de uma nação. Dentre suas funções mais nobres, podem ser citadas a vigilância dos poderes constituídos e a divulgação de informações efetivamente relevantes para o público. Falar em mídia é, inegavelmente, falar em vigilância do poder, e falar em imprensa livre é falar numa prática de comunicação social historicamente forjada pela modernidade que organiza o espaço público, o Estado e o mercado, segundo o primado dos direitos do cidadão.

A capacidade da mídia de fixar uma "agenda do dia", é uma das principais formas de influenciar a sociedade, exercendo um de seus principais papeis, qual seja, o de organizar o debate político. Tal função já seria suficiente para dar a medida da responsabilidade da mídia perante a

\footnotetext{
${ }^{21}$ FREITAS, Antonio Francisco de. Análise do discurso jornalístico: Um estudo de caso. Maceió Universidade Federal de Alagoas, 1999, p. 5-11.
} 
sociedade a qual deve servir, embora os órgãos da mídia não representem adequadamente os cidadãos, pois não são "eleitos", nem estão sujeitos a qualquer forma eficaz de controle ou fiscalização, etc.

É devido à falta de responsabilidade dos órgãos da mídia para com a sociedade que alguns autores questionam se a ela pode ser, efetivamente, considerada um dos legítimos poderes da República. Esta é a posição de Betch Cleinman, que questiona: "se constitucionalmente todo poder emana do povo, deve um grupo de empresas privadas, comandadas, não pelo bem comum, mas pela obtenção máxima do lucro, ser considerado um dos poderes da republicanos?" Em resposta, traz como lembrança, em seu artigo, o ensinamento do sociólogo português Boaventura de Souza Santos, quando cita que "quem tem poder para difundir notícias tem poder para manter segredos e difundir silêncios; tem sobretudo o poder para decidir se o seu interesse é mais bem servido por notícias ou por silêncios" ${ }^{22}$.

${ }^{22}$ CLEINMAN, Betch. Litígios de estrondo entre os $3+1$ Poderes da república. Cidadania $e$ Justiça. Rio de Janeiro, ano 3, n. ${ }^{\circ}$ 6, p. 22. 


\title{
Capítulo 4.
}

\section{A ética como cerne da atividade jornalística}

\subsection{Breve análise sobre a importância da responsabilidade jornalística}

Muito já foi dito em relação à questão do poder, da influência e da interferência da mídia na era da eletrônica e da instantaneidade - e, portanto, a sua responsabilidade social. O papel da imprensa na democracia, como já citado anteriormente, e sua relação com a violência e a criminalidade constituem temas para inúmeros seminários, debates, palestras, pesquisas, com as mais diversas conclusões, que possuem em comum a constatação de sua força e importância crescentes no mundo contemporâneo.

Como bem lembrado por Ester Kosovski no artigo Ética, Imprensa e Responsabilidade:

\begin{abstract}
"as notícias recebidas através da mídia eletrônica no exato momento em que acontecem (a transmissão da CPI da corrupção, por exemplo) despertam emoções e sentimentos variados e são apresentadas, selecionadas e comentadas 'a posteriori' pelos jornais e periódicos, cada um à sua feição, sendo consumidos por público mais reduzido, servindo de fonte permanente de referência futura. A mobilização, o impacto, a solidariedade ou até o pânico que uma imagem forte pode causar (crianças esquálidas e famélicas; uma ave encharcada de óleo no mar; as vítimas da guerra fraticida na Bósnia; o aperto de mai de Arafat e Rabin; a fragilidade esperançosa de Betinho) são exemplos marcantes, emblemáticos, como as imagens da chacina da Candelária, dos presos do Carandiru, dos Ianomamis, da favela de Acari, logo substituídas por outras na eterna tentativa, sempre renovada, de superar o seu próprio impacto" 23 .
\end{abstract}

Daí advém a responsabilidade em relação à sociedade, o que inclui o respeito para com a cidadania, algo que não pode ser delegado a apenas alguns - a responsabilidade é sempre compartilhada. O questionamento

\footnotetext{
${ }^{23}$ KOSOVSKI, Ester. Ética na Comunicação. Rio de Janeiro: Mauad, 1995, pp. 25-37.
} 
sobre se a violência e a criminalidade são exacerbadas pelos noticiários e jornais é controverso. Alguns estudos indicam, por exemplo, que a banalização de atos desviantes os tornam normais e corriqueiros. Outros, ao contrário, fazem uma leitura didática de certos programas, vinculando-os diretamente a eventos criminais, o que poderia ser comprovado com exemplos em diversos países.

Nos Estados Unidos, por exemplo, após a exibição na televisão de um filme em que um menino põe fogo em sua escola, ocorreram diversos casos de incêndios em escolas primárias, com a mesma forma de execução, em diferentes lugares. No Rio de Janeiro vários assaltos com reféns foram inspirados em fatos reais ou ficcionais, anteriormente veiculados.

A liberdade de expressão é, antes de tudo, um direito político, que tende a ser o primeiro a ser abolido nos regimes totalitários quando se tenta proteger tal governo da vigilância dos cidadãos informados. Para preservar e proteger a liberdade de expressão contra seus próprios eventuais abusos, portanto, deve ser utilizada como freio a valorização dos princípios éticos, fundados em valores universais consensualmente aceitos.

Para tanto, temos o Código de Ética para o jornalista, aprovado pelo Congresso de Jornalistas em 1985, no Rio de Janeiro, e modificado pelo XXI Congresso Nacional dos Jornalistas Profissionais, em 1986, em São Paulo, constituindo-se em 27 artigos assim distribuídos:

I - Do direito à informação;

II - Da conduta profissional do jornalista, título onde também estão relacionados os deveres;

III - Da responsabilidade profissional do jornalista.

O Código de Ética visa imputar a responsabilidade, recomendando sempre que sejam ouvidas as pessoas objeto de acusações não comprovadas, garantido a ampla defesa na imprensa, o respeito aos sujeitos 
mencionados e a permissão ao direito de resposta, quando ficar demonstrada a existência de equívocos.

No entanto, são cada vez mais freqüentes as transgressões ao código, seja porque as sanções previstas são pouco intimidativas, seja porque na verdade elas não cerceiam abusos. Há milhares de casos de jornalistas e jornais que respondem por processos criminais e civis, sem que mudem sua conduta. Existem, inclusive, órgãos que já prevêem, em seu orçamento, valores a serem utilizados no pagamento de indenizações a que são condenados quase que mensalmente.

\subsection{A recém revogada Lei de imprensa - Lei 5250/1967}

No Brasil vigorou até 2009 a Lei n. 5250, de fevereiro de 1967, a chamada "Lei da Imprensa", que regulava a liberdade de manifestação do pensamento e da informação, estabelecendo limites promulgados no período do totalitarismo. A lei incluía e tipificava uma serie de condutas, prevendo até mesmo pena de prisão, tal como seu artigo 17, in verbis:

Art . 17. Ofender a moral pública e os bons costumes:

Pena: Detenção, de 3 (três) meses a 1 (um) ano, e multa de 1 (um) a 20 (vinte) salários-mínimos da região.

Parágrafo único. Divulgar, por qualquer meio e de forma a atingir seus objetivos, anúncio, aviso ou resultado de loteria não autorizada, bem como de jogo proibido, salvo quando a divulgação tiver por objetivo inequívoco comprovar ou criticar a falta de repressão por parte das autoridades responsáveis:

Pena: Detenção de 1 (um) a 3 (três) meses, ou multa de 1 (um) a 5 (cinco) salários-mínimos da região.

O Supremo Tribunal Federal decidiu, em abril de 2009, ao julgar a ADPF n. ${ }^{\text {130/DF }}{ }^{24}$, por maioria de votos, revogar totalmente a Lei de

\footnotetext{
${ }^{24}$ STF, ADPF n. 130/DF, Rel. Ministro Carlos Ayres Britto, Brasília, 29 abril 2009.
} 
Imprensa. Sete ministros seguiram o parecer do relator, o ministro Carlos Ayres Britto, de que a legislação é incompatível com a Constituição Federal. Três foram parcialmente favoráveis à revogação, e apenas o ministro Marco Aurélio Mello votou pela manutenção da lei. "A quem interessa o vácuo normativo? A jornais, jornalistas, aos cidadãos em geral?", questionou o ministro.

O fim da lei editada em 1967 pelo governo militar ganhou o aval dos ministros Cesar Peluso, Ricardo Lewandowski, Carmen Lucia, Carlos Alberto Menezes Direito, Celso de Melo, Carlos Ayres Brito, relator do processo, e Eros Grau. Os ministros Joaquim Barbosa, Ellen Gracie e Gilmar Mendes votaram pela revogação de apenas alguns itens da legislação. Um dos principais argumentos utilizados foi a alegação de que a Lei de Imprensa foi editada num período de exceção constitucional, cujo objetivo foi o de cercear ao máximo a liberdade de expressão, com vista a consolidar o regime autoritário que vigorava no Brasil.

A Ministra Ellen Gracie e o ministro Joaquim Barbosa consideraram que deviam ser mantidos os artigos da lei que prevêem penas contra crimes de calúnia, injúria e difamação. Os ministros consideraram que "é importante mantê-los para coibir abusos não toleráveis pelo sistema jurídico. Às vezes, a imprensa pode ser destrutiva, não apenas em relação a agentes públicos. A imprensa pode destruir a vida da pessoa", afirmou Barbosa. Ele também criticou a concentração da mídia no Brasil, qualificando-a de "extremamente nociva para a democracia".

O ministro Menezes Direito apontou, ainda, uma incompatibilidade entre a Lei de Imprensa e a Constituição de 1988. Ele afirmou que na Constituição já há mecanismos para garantir a liberdade de imprensa com equilíbrio, como o direito de resposta. No entendimento do ministro, a limitação da imprensa pode trazer prejuízos à sociedade. 
Nota-se, portanto, que a discussão acerca dos limites éticos do jornalista serem regulamentados através de uma lei própria gera muita controvérsia em diversos setores institucionais no país, especialmente no jurídico. Apesar de revogada a antiga lei de imprensa, há diversos projetos de lei em análise, que buscam recriar a lei de imprensa de forma que esta se enquadre no contexto atual do país.

Em 2008, por exemplo, durante a III Conferência Legislativa sobre Liberdade de Imprensa, promovida na Câmara dos Deputados, representantes da mídia, parlamentares e associações de classe debateram a necessidade de elaboração de uma nova legislação específica para o setor. Apesar de não haver consenso sobre o tema, a opinião dominante, principalmente entre os empresários da área, é que qualquer regulamentação pode naturalmente resultar em algum tipo de restrição de liberdade, o que é intolerável num regime democrático.

Diversos foram os posicionamentos também fora do âmbito jurídico. Roberto Civita, presidente da Editora Abril, que publica a revista Veja, chegou a afirmar em entrevista que "na imprensa, como em todas as outras áreas em que se fala de liberdade, quanto menos legislação, melhor". "O jornalista, quando erra, tem de ser enquadrado pelos códigos Penal e Civil", defendeu Júlio César Mesquita, do Grupo Estado.

O deputado Miro Teixeira (PDT-RJ), autor da ADPF n. ${ }^{\circ}$ 130/DF, também em entrevista concedida à época do julgamento da ação, se manifestou no sentido de que "a Constituição assegura a liberdade de imprensa porque o direito à informação é essencial ao bom funcionamento da democracia. A mera existência de uma lei que restrinja esse direito é uma intimidação implícita”. Para o parlamentar, assim como um juiz ou um ministro desfrutam de imunidade para exercer plenamente suas funções, um jornalista deveria ter o mesmo direito, sem correr o risco de ser impedido pela Justiça. 
O presidente do Grupo Folha, Luís Frias, discordou da nãoregulamentação. Segundo ele, isso provocaria "um vazio jurídico" que poderia ser danoso à sociedade. O vice-presidente das Organizações Globo, João Roberto Marinho, advertiu que a fixação de indenizações exorbitantes também tem funcionado como uma forma de intimidação da imprensa.

O modelo proposto por Miro Teixeira foi inspirado no modelo norteamericano de democracia, que se empenha em preservar o livre exercício do jornalismo. Lá, como aqui, a discussão chegou aos tribunais: em 1964, um burocrata do governo do Alabama processou o jornal The New York Times por ter publicado um anúncio do ativista Martin Luther King contra as práticas racistas do estado. Alegando a defesa da honra, o burocrata ganhou uma indenização. Quando o jornal apelou à Suprema Corte, coube ao juiz Justice Brennan defender a tese de que a proteção da democracia e, por tabela, da imprensa - é mais importante do que a proteção da honra. "O debate sobre questões públicas deve ser livre, robusto e aberto, e pode muito bem incluir veementes, cáusticos e algumas vezes duros ataques ao governo e aos agentes públicos", escreveu o magistrado ao revogar a decisão que punia o jornal. $\mathrm{O}$ caso foi considerado um marco na história da garantia da liberdade de imprensa.

$\mathrm{Na}$ verdade, talvez um modelo de legislação complementar à Constituição seja realmente necessário para garantir a efetividade dos princípios e liberdades individuais previstos na Carta Magna. Não se trata de cercear a liberdade de expressão, como alguns pontuam - trata-se, apenas, de adequar a legislação às necessidades que surgiram com o abuso do poder da informação, que, muitas vezes, acarreta danos irremediáveis à pessoa, especialmente no que tange ao acusado ou investigado no âmbito jurídico-penal. 


\subsection{A necessidade dos limites éticos}

A realidade é que o sensacionalismo, uma das características inegavelmente presentes na maioria das publicações mais rentáveis, é eticamente reprovável, pois não é sinônimo de "jornalismo popular", como se costuma acreditar. É o jornalismo que se curva ao preconceito, pois no Brasil, jornal popular é considerado, geralmente, jornal de "baixo nível", embora haja formas de se produzir jornais acessíveis às classes mais baixas sem recorrer ao crime, à morbidez e ao escândalo.

O jornalismo investigativo, especialmente, é palco das maiores violações de direitos individuais, em clara violação às garantias constitucionais. Como já exposto em momento anterior, o jornalismo investigativo, quando realizado de forma inapropriada, acaba por extrapolar sua função jornalística, assumindo tarefas do âmbito de outras instituições (o Poder Judiciário), confundindo o consumidor em relação ao que é notícia e o que é especulação investigativa.

Carlos Alberto di Franco, em artigo publicado pelo jornal O Globo, coloca a questão relativa ao jornalismo investigativo, de acordo com a sua experiência. Expõe o seguinte: "perguntaram-me alguns, em seminários e debates, se o jornalismo de denúncia não estaria extrapolando as suas funções e assumindo tarefas reservadas à polícia e ao Poder Judiciário”. "Outros, ao contrário, preocupados com reiterados precedentes de impunidade, gostariam de ver repórteres transformados em juízes ou travestidos de policiais", relata o jornalista. "Um exame sereno, no entanto, indica um saldo favorável ao esforço investigativo dos meios de comunicação". É que, neste sentido, "o despertar da consciência da urgente necessidade de uma revisão profunda da legislação brasileira, responsável maior pelo clima de imoralidade nos negócios públicos, representa um serviço inestimável prestado pela imprensa deste país”. Além disso, “os 
meios de comunicação existem pra incomodar". O jornalista acredita que a imprensa, quando atua sem precipitação e injustos prejulgamentos, está desempenhando importante papel na recuperação da ética na vida pública. Mas assevera que "o Brasil depende, e muito, da qualidade ética da sua imprensa. A opinião pública espera que a mídia, apoiada nos crescentes aprimoramentos dos seus recursos humanos e nas balizas éticas, prossiga no seu ânimo investigativo"25.

É mais do que evidente, no entanto, que alguns jornalistas sentem-se acima de qualquer princípio ou ética, atuando como juízes em causas sérias, para as quais não estão preparados, sem qualquer indício de responsabilidade social.

No entanto, o jornalista precisa ter essa responsabilidade social, traduzida em limitações do trabalho jornalístico - não no sentido de limitar o conteúdo a ser investigado ou exposto. E sim com o objetivo de garantir que a exposição midiática seja feita de forma ética, garantindo, desta forma, um jornalismo que traz mais benefícios do que ônus aos investigados e à própria sociedade.

Se o direito à liberdade de imprensa é constitucionalmente garantido, o direito à paridade de armas e à ampla defesa, bem como à privacidade e à presunção de inocência, também o são, e devem se sobrepor a alguns princípios para a garantir de forma eficiente a democracia plena.

Numa exposição clara e objetiva, a articulista Patrícia Cruz assevera que "los principales lineamientos que deben seguir los médios de comunicación para cumplir com su función social de informar a la sociedad son: objetividad, veracidad, oportunidad y pluralidad"26.

Por outro lado, dentre os aspectos nos quais se podem identificar possíveis faltas à ética no exercício da atividade jornalística, compreendem-

\footnotetext{
${ }^{25}$ FRANCO, Carlos Alberto di. Imprensa, memória da cidadania. O Globo, Opinião, p.7, Rio de Janeiro, 19.08.2002.

${ }^{26}$ CRUZ, Patrícia. La Práctica de la ética en los médios de comunicación, p. 2.
} 
se: omitir informação, apresentar a informação acompanhada de adjetivos qualificativos, enfatizar somente um aspecto da informação, diferenças nos tempos atribuídos à informação sobre os atores, uso dos planos televisivos para exaltar ou atribuir demérito à imagem de alguns atores, não dar os antecedentes suficientes para entender a notícia, utilizar o meio de comunicação como tribuna para defesa ou autopromoção e indução nas perguntas durante as entrevistas, etc.

Em suma, partindo do pressuposto de que a busca pela verdade é uma atividade sempre ingrata para o jornalista, na medida em que ela sempre se apresentará diante dele como relativa, parcial ou fragmentária, cabe a ele assumir uma postura neutra e objetiva, respeitando o direito do púbico ao conhecimento da verdade, a partir da qual poderá formar sua opinião sobre o fato noticiado.

É importante, para isso, que o jornalista se qualifique abertamente como intérprete da realidade a qual trabalha, pois a partir daí poderá lançar mão de sua subjetividade, baseada na sensibilidade conquistada no exercício da profissão.

É imprescindível que seja garantida a manifestação por diversos ângulos ou pontos e vista sobre o fato objeto da notícia, privilegiando em seu trabalho a pluralidade de opiniões. Somente assim o jornalista terá ressaltado a importância de seu potencial transformador da sociedade em um projeto rumo à plena democracia - caso contrário, será apenas mais uma peça a servir de instrumento à minoritária classe dominante para manter e perpetuar o status quo da realidade social através da manipulação das notícias divulgadas. E se pudermos contar com a ajuda de uma legislação que assegure, efetivamente, o cumprimento do verdadeiro papel jornalístico do profissional, tanto melhor. 


\section{Capítulo 5.}

\section{A imagem da violência e a construção social da criminalidade}

\subsection{A política criminal sob a influência da mídia}

No que tange à matéria criminal, os órgãos da mídia normalmente separam de maneira simplista os personagens de suas tramas entre bons e maus, criando estereótipos frequientemente associados às classes populares da sociedade. Tal comportamento gera distorções na correta compreensão da realidade, o que leva a equívocos freqüentes.

É possível destacar, em qualquer dos órgãos da mídia, espaços dedicados à questão criminal, com nítida preferência a alguns tipos de crimes, previamente selecionados, que são reiteradamente exibidos, narrados e descritos constantemente. Neste cenário, é possível que tamanha quantidade de informações veiculadas exerça alguma forte influência no comportamento das pessoas em geral, o que é extensível aos sujeitos processuais - especialmente ao juiz.

O ILANUD - Instituto Latino-Americano das Nações Unidas para Prevenção do Delito e Tratamento do Delinqüente, órgão regional que compõe a Rede do Programa de Prevenção do Crime e Justiça Criminal das Nações Unidas (Crime Prevention and Criminal Justice Programme Network - PNI), ligada ao Conselho Econômico e Social da ONU, tem como função dar assistência à comunidade internacional na área da prevenção à violência e da justiça penal, promovendo a cooperação entre os países membros da ONU. Os membros desta rede têm como principais atividades a divulgação e a troca de informações, a formulação de pesquisas e o oferecimento de treinamento e de capacitação especializada no assunto. 
Em pesquisa realizada pelo órgão, ficou explícito que o crime é apresentado pela televisão de forma distorcida e parcial, enfatizando determinadas modalidades de comportamento em detrimento de outras, apresentando seus autores e vítimas ora como heróis, ora como vilões. Dáse maior destaque ao momento da descoberta do crime do que à sua explicação e resolução, sobrevalorizando a gravidade do fato, mesmo quando, na prática e no contexto em que ocorre, tal gravidade se dilui.

Os pesquisadores exemplificaram citando que:

“em 1998, a Associação Nacional de Televisão a Cabo tornou pública uma pesquisa levada a cabo ao longo de 3 anos em que se verificou 1) 40\% dos personagens maus não são punidos e 2) $40 \%$ dos personagens violentos são dados como positivos. Esse levantamento se baseou em 10.000 horas de programação das $6 \mathrm{~h} 00$ às $23 \mathrm{H} 00$. Ele demonstrou que os programas violentos totalizaram $61 \%$ do total e, mais ainda, comprovou que houve um aumento das temáticas consideradas violentas na televisão. Em 1996, elas representariam 53\% da programação que vai ao ar das 18 h00 às $21 \mathrm{~h} 00$. Atualmente já seriam $67 \%$. Segundo George Gerbner, da Escola de Comunicações da Universidade da Pennsylvania, as crianças americanas passariam em média 27 horas por semana diante da TV e, até atingir os 18 anos, teriam visto cerca de 40.000 assassinatos e 200.000 outros crimes violentos" 27 .

Segundo o professor português José Francisco de Faria Costa, "na verdade, a apreensão global e integrada do fenómeno criminal tornou-se, nos últimos tempos, não só em objecto privilegiado dos meios de comunicação social, mas, indesmentivelmente, transformou-se em seu objecto de culto". Em justificativa à preferência desde objeto de culto, o professor expõe que:

"em primeiro lugar, deve, desde logo, sublinhar-se o facto de que o fenômeno social crime desencadeia pulsões e mecanismos de sublimação que a comunicação se limita a aproveitar, quando não a exacerbar. Nesta perspectiva, o crime - concretização da transgressão - representa a notícia por autonomásia. E por quê? Porque é apelativo, suscita reacções imediatas de repulsa e adesão, deixa espaços para processo de transferência, tem personagens cómicas,

\footnotetext{
${ }^{27}$ DIMENSTEIN, Gilberto, e outros. ILANUD. Crime e TV. 2001, Revista n. ${ }^{\circ} 13$. O volume trata da forma o como tema da violência e os crimes são abordados pela televisão brasileira. O trabalho analisou 7 dias da programação das emissoras de televisão abertas e as cenas de violência veiculadas no período. Um dos principais resultados da pesquisa foi a constatação de que crimes de maior repercussão social como roubos e extorsão mediante seqüestro chegam a ser noticiados até quatro vezes mais do que ocorrem na realidade. A hiperexposição destes delitos contribui para a sensação de insegurança social e impunidade.
} 
dramáticas ou trágicas e o seu iter pela justiça penal constrói um arco de tempo longo, longuíssimo. O que permite, no que se refere a este último aspecto, que os media - cujos actos têm o tempo de vida efêmero, mas não os seus efeitos - os possam tratar retalhadamente ao longo do tempo" 28 .

De acordo com a mesma pesquisa realizada pelo ILANUD, a preferência dos consumidores é pela televisão como principal meio informativo e de entretenimento por ser ela um dos meios mais dinâmicos e acessíveis ao povo brasileiro. E especialmente neste veículo, as distorções se repetem quando a mídia passa a tratar dos crimes e das imagens do criminoso, que são reiteradamente representados em filmes exibidos no cinema, nas telenovelas etc.

Apenas exemplificando, o professor espanhol Vicente Garrido apurou, em análise realizada em uma semana de programação em cinco canais espanhóis de televisão, que foram apresentados aos telespectadores 686 disparos de armas de fogo, 654 lutas ou brigas, 427 homicídios, 67 roubos e furtos, 42 seqüestros, 31 cenas de utilização de drogas e 26 suicídios. $^{29}$

Sendo assim, a observação meramente quantitativa revela a importância estratégica da criminalização das relações sociais na mídia. Neste cenário, o surgimento de uma ideologia do medo exposta propositadamente pela mídia nacional e dirigida à sociedade é uma hipótese facilmente verificável.

O professor argentino Eugenio Raúl Zaffaroni já defendeu que "os meios de comunicação social de massa, especialmente a televisão, são hoje elementos indispensáveis para o exercício de poder de todo o sistema penal"30. A mídia participa fundamentalmente em dois níveis: em nível transnacional, os meios de comunicação de massas ocupam-se da precoce

\footnotetext{
${ }^{28}$ FARIA COSTA, José Francisco. Direito penal da comunicação. Coimbra: Coimbra Editora, 1998, pp. 131-132.

${ }^{29}$ GARRIDO, Vicente; STANGELAND, Per; REDONDO, Santiago. Principios de Criminología. $2^{a}$ Ed., Valencia: Tirant lo Blanch, 2001, p. 871.

${ }^{30}$ ZAFFARONI, Eugenio Raúl. Em busca das penas perdidas: A perda da legitimidade do sistema penal. Rio de Janeiro: Revan, 1991, p. 127-128.
} 
introjeção do modelo penal como um pretenso modelo de solução dos conflitos através da "comunicação da diversão"; em nível das conjunturas nacionais, os meios de comunicação de massa têm a função de gerar a ilusão da eficácia do sistema, criando um quadro em que apenas a iminência de morte violenta por ladrões ou quadrilhas seja percebida como perigo.

De um lado, o material transnacionalizado, tal como as séries policiais, cria uma expectativa de que os membros das agências penais nacionais devem comportar-se como os personagens das séries. Além disso, os programas glorificam o personagem violento que aniquila o "mau", trazendo como solução do conflito a supressão desta idéia do "mau", o que gera um desprezo pela dignidade das pessoas e pelas garantias individuais, tornando-se mais uma propaganda em favor do reforço do poder e do controle social verticalizado-militarizado de toda a sociedade.

É perigoso, porém, que a audiência julgue como criminoso alguém que ainda não passe de um mero suspeito, e que, como tal, ainda possa vir a ser inocentado num processo judicial que não será exibido na televisão, ou o é com lapso temporal tão grande que a declaração de inocência não consegue mais apagar as primeiras impressões. É grave, também, que se avalie a criminalidade a partir de atos isolados, não inseridos num contexto explicativo que relativize a sua importância ou que lhes confere a sua real dimensão.

A criação do estereótipo do criminoso origina um sistema penal que atua seletivamente, agindo de acordo com estereótipos fabricados pelos meios de comunicação em massa. Inventa-se, assim, uma nova realidade através dos meios de comunicação, caracterizado pelo aumento desproporcional e distorcido do espaço midiático destinado aos episódios violentos. E tanto a criminalidade como a violência, enquanto fenômenos, se tornaram mais comunicacionais do que experimentais, pois podem ser assistidos pela televisão sem que haja a necessidade de ser vivenciados pessoal ou diretamente pelo espectador. 
Por esse motivo, vive-se hoje a exagerada sensação generalizada de que há uma "zona de guerra” próxima, invisível e à espreita - o sentimento de insegurança a perturbar a tranqüilidade da sociedade. É a penetração da ideologia do medo, inevitável, uma vez que a própria sociedade é convenientemente manipulada pelos órgãos da mídia que estão geralmente em busca de um maior grau apelativo e romanceado, mais economicamente rentável. As verdades inculcadas nas pessoas, especialmente as de classes mais baixas, com menor capacidade crítica, é muito distorcida da realidade, e esta nova realidade tem como principal característica o julgamento das condutas e dos fatos, muito mais do que uma informação em si.

Em citação, o professor Raúl Cervini lembra que:

"Nilo Batista, en um ilustado artículo identifica principios caracterizantes del mercado de la información sobre la violencia. Estos son: 1) principio de la verdad originaria. Señala este autor que la primer noticia de un periodico sobre un hecho criminal que él mismo investigo o que divulga com exclusividad, se constituye em dogma, matriz y hilo conductor de toda la información siguiente. 2) principio de la progressividad: significa que la violência progressiva (continuada, organizada) vende más que la violência episódica (individualizada o circunscripta) siempre que sea posible los casos aislados deben ser articulados en un contexto de progressividad. 3) principio de la plus valía de la violencia impune: El caso criminal inmediatamente resuelto merece menos espacio que aquel pendiente de resolución; 4) principio de la manipulación estadística: las estadísticas deberán siempre y necesariamente confirmar la hipótesis de inseguridad generalizada e inoperância del aparato de control formal; 5) principio de la ineficácia del Estado: la violencia social deberá ser atribuida siempre a la ineficiencia del Estado y jamás se debe convertir en objeto de discussión a la própria organización social; 6) principio de la credibilidad inmediata del terror: en la cobertura periodística de un caso policial, el espacio otorgado a un testimonio será directamente proporcional a mensaje atemorizando que é contenga; 7) principio del estereotipo criminal: la criminalidad se concentra en determinado rango social y racial"31.

O resultado da aplicação dos princípios acima citados sobre a realidade é a constatação de que a informação tem potencial criminógeno, com alto poder de influência sobre a sociedade. A informação criminógena, que é a divulgação de fato de natureza anti-social através dos meios de comunicação de massa, pode ter um efeito sobre os comportamentos dos

\footnotetext{
${ }^{31}$ CERNIVI, Raúl. Revista CEJ. Nuevas Reflexiones sobre Extravictimización Mediática de los Operadores de la Justicia. Brasília, n. ${ }^{\circ}$ 20, pp. 40-41, dez. 2002.
} 
receptores, suscetíveis de influência ou dependência. São nítidas as manifestações psico-sócio-culturais ou eventuais potencialidades para o desvio de condutas influenciadas pelo efeito da mídia.

É evidente que são vários os fatores que podem exercer influência nos receptores dessas informações transmitidas pelos meios de comunicação. Algumas dessas variáveis são o problema da aculturação do receptor, seu grau de instrução e a força de penetração dos meios de comunicação de massa, bem como seu sexo, idade, meio em que vive, etc.

O impacto causado é, portanto, o grau de intensidade da informação, cujos valores quantitativos e qualitativos atingem a opinião pública e influem no comportamento do receptor ou da comunidade suscetível de contágio. O impacto torna-se criminógeno quando sua apresentação ou interpretação influem de forma negativa no comportamento individual ou coletivo, predispondo para o ato anti-social.

O impacto fortalece a informação quando acrescenta valores que enfatizam o seu entendimento, ao contrário do sensacionalismo, que funciona como a desnaturação do impacto, na vulgarização da informação. A função da criminologia, por fim, não é a de intervir no processo informativo quanto ao seu conteúdo, e sim quanto ao critério de divulgação, tendo em vista o comportamento do homem dentro do grupo social.

O defeito ético que se verifica no jornalismo sensacionalista, como já demonstrado anteriormente, é a maneira de dizer e de mostrar notícias sobre fatos que, na maioria das vezes, já são chocantes pela sua própria natureza. E assim consegue-se separar a mera exploração mercantilista do voyerismo do horror da informação devida ao público. É chocante verificarmos que a mídia muitas vezes foca suas câmeras sobre o rosto de quem acaba de sofrer uma tragédia pessoal, explorando a dor alheia. Nota-se, portanto, que tanto a parte investigada, já condenada aos olhos da imprensa, como a vítima, sofrem ambos as conseqüências das irresponsabilidades dos jornalistas. 
$\mathrm{O}$ argumento geral dos jornalistas, mesmo daqueles que condenam o sensacionalismo em justa defesa da liberdade de imprensa, pode ser resumido no argumento de que "a imprensa não produz os fatos, apenas os relata de forma neutra". Sabemos, contudo, que tal argumento é falacioso e utilizado indevidamente em defesa de uma justa causa. A neutralidade da imprensa é um mito inalcançável, na prática - é no máximo um ideal, que os órgãos da mídia conseguem tangenciar.

Desta forma, somada a impossibilidade de neutralidade total da mídia aos fatores criminógenos eventualmente existentes nas notícias, temos evidências de seu poder de influência. Segundo José Flávio Braga Nascimento, "a Comissão Nacional sobre causas e prevenção da violência nos Estados Unidos deu especial importância à influência que exerce os modernos meios de comunicação maciça no comportamento violento, e mais precisamente a televisão". Citou ainda que a Comissão, naquela ocasião, verificou "que existem preponderantes evidências, sugerindo de forma determinada que a violência dos programas de televisão podem ter e têm efeitos adversos sobre a audiência, particularmente quando se trata de crianças". A televisão, especialmente, tem muito poder no processo educativo dos menores, ensinando valores morais e sociais sobre a violência que são contrários às normas de uma sociedade civilizada.

Luiz Flávio Gomes, em seu artigo doutrinário Mídia e Criminalidade, veiculado através do site do Instituto Brasileiro de Ciências Criminais - IBCCrim, reproduz algumas conclusões sintetizadas pelo medico Drázio Varella, em matéria jornalística anteriormente publicada no periódico Folha de São Paulo:

“(a) quanto maior o número de horas diárias (diante da televisão), mais freqüente a prática de crimes violentos por esses telespectadores; (b) adolescentes e adultos jovens expostos à TV por mais de três horas por dia contam com probabilidade de praticar atos violentos cinco vezes mais em relação aos que assistem menos de uma hora; (c) o efeito deletério da violência na televisão atinge todas as faixas etárias, particularmente as crianças e os adolescentes; (d) todos os dados pesquisados apontam impressionantemente para 
uma conexão causal entre a violência na mídia e o comportamento agressivo das pessoas" $" 32$.

Há grandes interesses em jogo e abundantes provas científicas de que a mídia influencia o telespectador, fato do qual o receptor da informação deve ser conscientizado. É lamentável, sem dúvida, que cada vez seja mais comum a subutilização dos potenciais positivos dos órgãos da mídia, especialmente a televisão, que em vez de promover uma atividade voltada à orientação insiste em criar, reproduzir e manter produtos supostamente informativos, de baixíssima qualidade. E não há, na realidade, qualquer interesse por parte dos responsáveis por esta subutilização para que esta situação se modifique.

Alguns autores defendem o efeito neutro da atuação da mídia, tal como o professor Nilo Batista. O autor defende que não há, na prática, demonstrações concludentes de que a representação de cenas violentas provoque um efeito criminológico direto e imediato.

Outros autores defendem, ainda, a existência de efeitos positivos neste tipo de atuação da mídia - o professor espanhol Vicente Garrido explica que "uma hipótesis sobre el efecto de las escenas violentas en los espectadores es la de la catarsis: En vez de actuar agressivamente para aliviar tensiones y frustraciones de la vida diária, uno se siente satisfecho al ver la violencia en la televisión". Desta forma, a violência televisiva teria um efeito redutor da atuação violenta, além de que, como normalmente os delitos são esclarecidos e os "bons" se salvam enquanto os "maus" são punidos, haveria também um efeito de reforço dos valores legais.

De uma forma ou de outra, é válido ressaltar que, ainda que existam alguns poucos aspectos positivos na forma de influência da mídia na política criminal, tais aspectos certamente não superam as consequiências negativas. Se a influência sobre as crianças e seu potencial criminógeno não

\footnotetext{
${ }^{32}$ GOMES, Luiz Flávio. Mídia e criminalidade. Disponível na internet: www.ibccrim.org.br, 06.07.04.
} 
podem ser comprovados com total certeza pela comunidade científica, é inegável que, ao menos no âmbito jurídico-processual, há muitas conseqüências para todos os atores do processo, especialmente para o réu e para a vítima, focos das notícias sensacionalistas que transformam qualquer fato em uma aberração jurídica, se for conveniente para os que detêm o controle dos órgãos da mídia.

\subsection{Mídia e poder na Democracia}

Guy Debord definiu as sociedades contemporâneas como "sociedades do espetáculo", nas quais a representação tornou-se a principal forma de entrar em contato com as experiências da vida. A imagem foi eleita como o mecanismo mais eficaz de representação da realidade, e no Brasil, especificamente, vem se solidificando a idéia de que o que é veiculado pela mídia não só define os rumos da política criminal, mas também desvia a atenção das verdadeiras causas dos problemas sociais.

A banalização da ética humana, verificada com a mercantilização dos fatos relacionados à natureza humana, e a divulgação da vida dos sujeitos, converte em espetáculo alguns fatos selecionados pelos grupos de interesse, enquanto milhares de pessoas permanecem impedidas de exercer direitos constitucionais mínimos, como o acesso à saúde, à educação, à privacidade, etc. Para estas pessoas não se concretiza a dignidade humana tal como prevista na constituição, e para muitas delas o caminha encontrado é a delinquiência, que se não é determinada pela miséria humana, certamente é por ela influenciada. E assim a imagem do crime sustenta o discurso de que precisa se valer para gerar lucros, e para isso se utiliza do "inimigo" para se legitimar.

O poder de influência da mídia é tamanho que invadiu até mesmo as escolhas políticas dos cidadãos, se transformando num verdadeiro vetor da 
política criminal no Brasil. Diversas leis criminais são promulgadas em razão da cobertura que os meios de comunicação destinam a determinados episódios. Um dos exemplos mais emblemáticos é a Lei dos Crimes Hediondos (Lei n. ${ }^{\circ}$ 8.072, de 25 de julho de 1990), cujos excessos são afrontados até hoje pela comunidade jurídica. Da mesma forma, podemos citar o Regime Disciplinar Diferenciado (objeto da Lei brasileira ${ }^{\circ}{ }^{10.792,}$ de1. ${ }^{\circ}$ de dezembro de 2003, que alterou a Lei de Execuções Penais e o Código de Processo Penal), que veio a confirmar a tendência do recrudescimento da intervenção penal a partir de como a mídia o veicula.

E assim o processo penal é transformado, freqüentemente, numa arena virtual, em que os espectadores torcem com o réu. É desta maneira que se busca justificar a dinâmica do crescimento e do agravamento da resposta penal, utilizando-se de um discurso da defesa social em que a criminalidade é uma doença letal, e o criminoso, um agente de contaminação.

Posteriormente será discutida a questão dos princípios, mas é válido lembrar desde já que a liberdade de expressão, imprescindível ao Estado de Direito, tem como objetivo defendê-lo, num contexto de legitimação social em que os recursos empregados pela mídia, sua pretensões e suas conseqüências sejam também submetidos aos princípios constitucionais que estabelecem limites à atuação das instituições democráticas.

Justamente devido ao poder da mídia, não se pode permitir seu funcionamento como máquina de alienação do indivíduo, como lugar de exposição do banal e como empresas de manipulação do poder estatal e da política criminal.

O professor Álvaro Filipe Oxley da Rocha, sustentou brilhantemente em seu artigo Criminologia e Mídia: Sistema Penal em luta por poder simbólico, que: 
"O campo jornalístico luta pelo monopólio discursivo sobre a mesma "verdade" sustentada pelo sistema penal, mas apenas como forma de legitimação sobre a audiência e, portanto, para a consolidação de seu poder simbólico. Entretanto, o fato de orientar suas ações pela busca de lucro financeiro e/ou simbólico, sem preocupar-se com o bem comum, faz com que a mídia perca a legitimidade para a obtenção de efeitos sociais reais e duradouros. Arrisca-se, portanto, nesse processo, a deslegitimar ou a enfraquecer o poder simbólico estatal ou público, criando as condições para a instabilidade institucional e para o agravamento da instabilidade social. Entretanto, é preciso observar que a luta da mídia por poder simbólico, se justifica apenas pelos lucros que ocorrem durante a dinâmica da luta. Isso implica dizer que a mídia não pode levar sua luta às últimas consequiências, pois isso implicaria no disparate de vir a mídia a tomar o lugar do Estado, assumindo o poder político originado da posse reconhecida do poder simbólico, devendo, a partir disso, assumir as funções do Legislativo, do Executivo e do Judiciário, e especialmente as funções do sistema penal, algo a que as empresas de comunicação não se propõem, limitando-se à busca de legitimação como ator político em posição privilegiada, já que dotado de supremacia sobre os atores tradicionais, efeito, contudo, ilegítimo, pois decorre da crença geral em um "poder" simbólico, criado e difundido pela mesma mídia, e também porque as empresas de comunicação estão abertamente orientadas para o lucro financeiro, e não para o bem de todos, como o é o Estado, conforme a Constituição Federal Brasileira. (...)

No que se refere ao sistema penal, destacado aqui como parte do campo jurídico, este último inserido no grande campo do Estado, é preciso ter presente que a interação com a mídia pode produzir o resultado positivo de conscientizar os cidadãos sobre os problemas que aquele apresenta no que se refere, por exemplo, às falhas na legislação e na execução penal, à violência urbana descontrolada, aos problemas objetivos e éticos dos organismos de controle social (Judiciário, Ministério Público, Polícias etc.). Entretanto, dessa interação também surgem, por exemplo, os aspectos negativos da banalização, pela mídia, de temas penais de extremo relevo, a difusão do medo social, a omissão da maioria dos graves problemas que estão na origem da criminalidade, como a miséria, o analfabetismo, o desemprego, a injustiça social etc., por estes demandarem profundas análises científicas interdisciplinares, e sua solução, ou condução a níveis toleráveis, necessitar da implementação de políticas públicas adequadas, de médio e longo prazo, as quais, entretanto, não produzem os freqüentes escândalos de que necessita a mídia, em sua ansiosa busca por "novidades" atrativas ao público, que permitem valorizar financeiramente os espaços comerciais de seus canais de comunicação, junto aos seus anunciantes/patrocinadores, e disputar o poder simbólico com o Estado, especificamente com o sistema penal. Mídia e sistema penal têm, portanto, objetivos muito diferentes, os quais se aproximam apenas no que se refere à disputa pelo poder resultante da afirmação da "verdade"

O poder da mídia, quando se insere indevidamente num contexto político, passa a produzir intencionalmente personagens e realidades que, em síntese, acarretam o reconhecimento da cidade como lugar característico de perigos, tensões, insegurança, medo e pânico. Há um caráter cíclico na

\footnotetext{
${ }^{33}$ ROCHA, Álvaro Filipe Oxley da. Criminologia e mídia: Sistema penal em luta por poder
} simbólico. In Boletim IBCCRIM. São Paulo : IBCCRIM, ano 18, n. 211, p. 01-02, jul., 2010. 
articulação de elementos que, unidos em etapas sucessivas no imaginário social, engendrados pela divulgação sensacionalista e massiva dos fatos violentos, aprofundam ainda mais a crise social do país. Os principais elementos engendrados são a exclusão do "outro", a construção social e simbólica da criminalidade, a demonização das classes populares, o sentimento generalizado de insegurança e a política criminal simbólica e seletiva sob influência direta da atuação da mídia.

Primeiramente, é válido ressaltar que violência e criminalidade não podem ser utilizadas como expressões sinônimas - há tipos de violência que claramente não são considerados crimes pela legislação penal, tal como a injusta distribuição de renda do Brasil, que poderia perfeitamente ser considerada uma forma de violência social, política e econômica. Da mesma forma, há diversos tipos de crime nos quais a violência em si não é empregada, tais como estelionatos, fraudes, etc.

Percebe-se, portanto, que a violência e a criminalidade são utilizadas pelos meios de comunicação de forma direcionada aos propósitos não só econômicos, mas político-ideológicos das classes dominantes. Busca-se confundir o consumidor em relação aos dois conceitos com o uso indevido dos dois problemas como sinônimos.

De acordo com Diego Ayres Corrêa:

"o discurso dominante novamente tenta ludibriar a percepção da realidade, com a referida visão parcial da violência, buscando associá-la exclusivamente aos atos delituosos, quando, na verdade, é inegável que a violência constitui-se fenômeno de abrangência muito mais ampla do que a criminalidade, não ficando adstrita tão-somente às ações ou aos atos delituosos" $" 34$.

Nas imagens veiculadas pela mídia há, geralmente, uma clara associação da pobreza com a violência e a criminalidade, efeito de um

34 CORRÊA, Diego Ayres. Os meios de comunicação de massa e sua influência no desenvolvimento da histeria punitiva e na ampliação da repressão penal. Revista de Estudos Criminais. Sapucaia do Sul: Instituto Transdisciplinar de Estudos Criminais - ITEC!, ano 1, n. 3, pp. 96-105, 2001. 
perverso processo de difusão do preconceito, o que, por sua vez, também estreita ainda mais a relação entre tais problemas, gerando um ciclo vicioso que tende a uma contínua perpetuação.

Sob a perspectiva da psicologia social, a autora Silvia Leser de Mello explica que:

\begin{abstract}
"ou reconhecemos no outro um semelhante, e nesse caso conferimos a ele os mesmo atributos de humanidade que encontramos em nós, ou não reconhecemos no outro um semelhante.(...) Para as classes dominantes é difícil reconhecer um igual nas personagens da pobreza. Reconhece-se o diferente como desigual. (...) Da desigualdade à inferioridade não há muita distância. Da desigualdade reconhecida como inferioridade e do desconhecimento ao temor, do ponto de vista psicológico, não há, também, grande distância. (...) O medo à desordem e à perda da vida e das propriedades, um grande descrédito na polícia e na justiça podem transformar a insegurança e o temor difusos em acusações contra segmentos sociais ou grupos específicos de sujeitos de quem se desconfia, que não são reconhecidos como iguais, ou seja, não são portadores da mesma humanidade que reconheço em mim e nos meus iguais" ${ }^{35}$.
\end{abstract}

Um dos principais exemplos da extensão do problema social originado com política de pânico e medo difundida pela mídia é a polícia. Ela é, sem dúvida, a instituição que mais se atrela às idéias difundidas pela imprensa, a partir de seu poder de influência social. E com isso, a instituição não consegue se colocar à altura da sociedade democrática de direito, pois é neste meio onde mais se verificam práticas verdadeiramente desmerecedoras de sua elevada função social. E este comportamento é tratado com a conivência da sociedade, que observa a impunidade com a qual o policial mata nas grandes cidades, legitimados pela sede de punição propagada pelos veículos de comunicação.

O interesse verificado com a propagação dessa falsa realidade social é em um único sentido: do ponto de vista do consumo é o sensacionalismo; do ponto de vista ideológico, por sua vez, trata-se da criação do medo ou pânico, o qual se agrega à insegurança amplamente divulgada pelos órgãos

\footnotetext{
${ }^{35}$ MELLO, Silvia Leser de. A cidade, a violência e a mídia. Revista Brasileira de Ciências Criminais. São Paulo: Revista dos Tribunais6, n. 21, pp. 189-195, jan.-mar. 1998.
} 
da mídia e sentida pela sociedade. E assim surgem os sucessivos clamores da sociedade pugnando o endurecimento do sistema penal.

Sendo assim, seja através da divulgação sensacionalista de notícias envolvendo crimes, seja através da criação e reforço das chamadas "ondas de crimes", ideologicamente a mídia objetiva à criação do pânico e medo da sociedade, via sentimento de insegurança. E através dos estereótipos e estigmas, lançados nos alvos privilegiados do sistema penal articulado ao discurso político da mídia, definem-se aqueles cidadãos e grupos que estão devidamente inseridos no contexto social adequado, ou seja, quem é consumidor, quem é desempregado, favela, pobre, etc.

A criação do sentimento generalizado de insegurança, portanto, atende a certos interesses políticos e econômicos bem identificados, especialmente o de desviar a atenção pública de acontecimentos nacionais mais importantes. O crescimento do uso de segurança privada também poderia ser visto como um foco de interesse na questão da insegurança pública e na utilização do poder da mídia para garantir a rentabilidade de um certo tipo de serviço oferecido por algumas empresas.

Desta forma, a atuação política desempenhada pelos órgãos da mídia, através da exploração sensacionalista na divulgação de suas notícias sobre crimes, criminosos e processos penais origina necessariamente a formação de uma opinião favorável a políticas repressivas e desgastadas, insistindo na aplicação rigorosa de um direito penal simbólico, emergencial e fracassado.

Concluindo, é válido ressaltar que, dentre todas as formas de influência da mídia, decorrentes do poder destes órgãos, a mais grave é a influência na visão política da sociedade. Esta passa a confundir o poder da mídia com o poder do Estado, de punir e julgar, e aceita as personificações estabelecidas pelas notícias que tentam colocar em estereótipos os problemas sociais. 
A democracia passa, então, a deixar de ser uma forma de representação da sociedade como um todo, uma vez que as classes dominantes, minoritárias, exigem de seus políticos que se posicionem contra as figuras estabelecidas do inimigo público - esquecem que a sociedade é composta de vários nichos, e que todos devem ser abrangidos pelo regime da democracia.

Elizabeth Rondelli expõe, neste sentido, que:

"a violência e suas imagens tornam-se fontes de significações culturais, pretextos para sustentar visões de mundo e práticas sociais, traduzindo a força da produção de sentidos, a vitalidade dos discursos que, ao induzirem tais práticas, ganham materialidade. Assim, engendram ações, aliciam e/ou constroem sujeitos, implementam e legitimam políticas",36.

${ }^{36}$ RONDELLI, Elizabeth. Mídia e Violência: Ação testemunhal, práticas discursivas, sentidos sociais e alteridade. Comunicação e Política. Rio de Janeiro, vol. 4, n. 3, p. 156, out.-dez. 1997. 


\section{Capítulo 6.}

\section{A colisão de direitos fundamentais: liberdade de expressão e informação $X$ direito a um julgamento criminal justo}

\subsection{Introdução}

Dentre tantos direitos fundamentais que poderiam ser citados neste trabalho, potencialmente violados com a atuação irresponsável da mídia, o foco será a colisão dos direitos fundamentais à liberdade de expressão e a um julgamento criminal justo. Tais direitos englobam subprincípios correlatos, tais como a presunção de inocência, o direito ao juiz imparcial, o princípio da verdade processual e da vedação da prova ilícita, e ainda o princípio da liberdade processual.

Após a análise dos fatores abstratos que, criados pela mídia, influenciam não só o processo penal, mas toda a sociedade, é pertinente focar no principal problema do abuso da mídia em seu papel, no âmbito jurídico: a publicidade opressiva dos julgamentos criminais.

Embora não haja, no Brasil, precedentes jurisprudenciais que tenham examinado o risco de interferência indevida da cobertura jornalística de julgamentos criminais, tal debate já é travado há anos pela Suprema Corte norte-americana, e também já recebeu especial atenção da Corte Européia de Direitos Humanos. Tais experiências são consideradas standarts, que podem ser utilizados pelo judiciário brasileiro, já que o fato de não haver precedentes não significa que o fenômeno trial by media não ocorra no Brasil - apenas não se deu a ele o tratamento constitucional adequado. 


\subsection{Liberdade de Expressão e Informação X Direito a um julgamento criminal justo}

A justificativa teórica da liberdade de expressão, um dos direitos mais aclamados nos tempos modernos, é que esta desempenhou um papel chave na fundação do Estado Constitucional, por se constituir uma premissa para a manutenção do Estado e de realização dos direitos fundamentais. Alguns fundamentos podem ser citados como base para o reconhecimento da importância desta concepção:

1) Nos regimes democráticos, apoiados na soberania popular, deve ser garantido o direito de criticar livremente os agentes públicos e de sustentar idéias que divirjam do senso comum. Até mesmo as opiniões minoritárias devem ser toleradas e combatidas apenas no campo das idéias;

2) O livre embate de idéias é imprescindível à descoberta da verdade, estando a verdade, por sua vez, associada à tomada das melhores decisões e à adoção das melhores políticas;

3) A proibição de discursos políticos extremistas propicia um ambiente de instabilidade política e enfraquece o Governo. Os regimes democráticos devem conviver com certo grau de instabilidade provocado pela livre veiculação de teses.

É necessário que o Estado tenha uma ação regulatória para garantir a qualidade do debate público, uma vez que o exercício responsável do autogoverno depende de cidadãos qualificados e munidos de informações suficientes no que tange aos assuntos de política e de governo, aptos a participar efetivamente da gestão da coisa pública, para garantir o bom funcionamento da democracia.

O fundamento que pugna pela posição preferencial da liberdade de expressão ressalta a relevância desse direito para a formação da opinião 
pública pluralista, instituição imprescindível ao regime democrático. Contudo, tal prevalência deve estar subordinada à importância do discurso para a formação da opinião pública. Ou seja, apenas se o conteúdo da manifestação for considerado pertinente ou relevante, lhe será conferida prevalência sobre direitos colidentes. Deve-se, portanto, ser avaliado se o fato noticiado é de interesse público.

Citando as palavras da juíza Simone Schreiber acerca especificamente do funcionamento do Poder Judiciário neste contexto:

"cumpre ressaltar que o cometimento de um delito é um fato de repercussão pública. E, indiscutivelmente, o funcionamento do Poder Judiciário é um assunto de interesse público, havendo legítimo interesse da sociedade nas notícias veiculadas a respeito de julgamentos em curso. O direito de crítica aos agentes públicos se estende aos juízes e autoridades que atuam perante o Poder Judiciário. Não obstante isso, ainda que se reconheça que a divulgação de notícias, opiniões e críticas, a respeito de julgamentos criminais em curso, seja tributária de proteção, isso não obsta que tal direito ceda em situação de colisão com o direito do réu a um julgamento justo e imparcial”"37.

O primeiro passo a ser dado no sentido de garantir o espaço de cada direito é exigir-se a veracidade dos fatos informados, considerada como requisito da liberdade de informação. É o compromisso para com a verdade que justifica a proteção da veiculação de informações verdadeiras contra quaisquer tentativas de censura ou punição. Mas este critério é muito subjetivo, como já vimos em capítulo anterior.

A Constituição Federal de 1988 contém diversos dispositivos que tratam da liberdade de expressão e dos serviços de comunicação, verbis:

Art. $5^{\circ}$ Todos são iguais perante a lei, sem distinção de qualquer natureza, garantindo-se aos brasileiros e aos estrangeiros residentes no País a inviolabilidade do direito à vida, à liberdade, à igualdade, à segurança e à propriedade, nos termos seguintes:

IV - é livre a manifestação do pensamento, sendo vedado o anonimato;

\footnotetext{
${ }^{37}$ SCHREIBER, Simone. A publicidade opressiva de Julgamentos Criminais. 1. ${ }^{\text {a }}$ Ed. Rio de Janeiro: Renovar, 2008, p. 91.
} 
$\mathrm{V}$ - é assegurado o direito de resposta, proporcional ao agravo, além da indenização por dano material, moral ou à imagem.

IX - é livre a expressão da atividade intelectual, artística, científica e de comunicação, independentemente de censura ou licença;

X - são invioláveis a intimidade, a vida privada, a honra e a imagem das pessoas, assegurado o direito a indenização pelo dano material ou moral decorrente de sua violação;

XIV - é assegurado a todos o acesso à informação e resguardado o sigilo da fonte, quando necessário ao exercício profissional;

Art. 220. A manifestação do pensamento, a criação, a expressão e a informação, sob qualquer forma, processo ou veículo não sofrerão qualquer restrição, observado o disposto nesta Constituição.

$\S 1^{\circ}$ - Nenhuma lei conterá dispositivo que possa constituir embaraço à plena liberdade de informação jornalística em qualquer veículo de comunicação social, observado o disposto no art. $5^{\circ}$, IV, V, X, XIII e XIV. artística.

$\S 2^{\circ}$ - É vedada toda e qualquer censura de natureza política, ideológica e

\section{$\S 3^{\circ}$ - Compete à lei federal:}

I - regular as diversões e espetáculos públicos, cabendo ao Poder Público informar sobre a natureza deles, as faixas etárias a que não se recomendem, locais e horários em que sua apresentação se mostre inadequada;

II - estabelecer os meios legais que garantam à pessoa e à família a possibilidade de se defenderem de programas ou programações de rádio e televisão que contrariem o disposto no art. 221, bem como da propaganda de produtos, práticas e serviços que possam ser nocivos à saúde e ao meio ambiente.

$\S 4^{\circ}$ - A propaganda comercial de tabaco, bebidas alcoólicas, agrotóxicos, medicamentos e terapias estará sujeita a restrições legais, nos termos do inciso II do parágrafo anterior, e conterá, sempre que necessário, advertência sobre os malefícios decorrentes de seu uso.

$\S 5^{\circ}$ - Os meios de comunicação social não podem, direta ou indiretamente, ser objeto de monopólio ou oligopólio.

$\S 6^{\circ}$ - A publicação de veículo impresso de comunicação independe de licença de autoridade.

Art. 221. A produção e a programação das emissoras de rádio e televisão atenderão aos seguintes princípios:

I - preferência a finalidades educativas, artísticas, culturais e informativas;

II - promoção da cultura nacional e regional e estímulo à produção independente que objetive sua divulgação; 
III - regionalização da produção cultural, artística e jornalística, conforme percentuais estabelecidos em lei;

IV - respeito aos valores éticos e sociais da pessoa e da família.

Tais normas veiculam a garantia da liberdade de expressão em sentido amplo, sobressaindo seu aspecto negativo. Trata-se de direito de defesa que assegura aos indivíduos uma esfera de liberdade, no âmbito da qual não se admite ingerência estatal. Contudo, a resposta deve referir-se estritamente aos fatos retratados na publicação ofensiva, não podendo conter expressões caluniosas, difamatórias ou injuriosas, dentre outras limitações éticas. Isto porque a Constituição, ao mesmo tempo em que veda a censura, prevê expressamente a responsabilização ulterior do emissor da mensagem (art. 5. ${ }^{\circ}, \mathrm{V}$ e X).

Acerca do direito a um julgamento criminal justo, no modelo brasileiro as normas que regem a apuração de fatos criminosos e a responsabilização de seus autores têm a função precípua de limitar a atividade persecutória, de modo a assegurar que o poder estatal nessa matéria seja exercido de forma racional e não arbitrária. Assim sendo, o processo penal possui garantias constitucionais que visam garantir o julgamento justo, o qual é premissa de validade e legitimidade da imposição de pena aos criminosos do Estado constitucional e democrático.

O principal embate entre a prerrogativa do Estado de restringir direitos individuais em relação à esfera de liberdade individual que não pode ser invadida pelo Estado, é, de um lado, o interesse público de perseguir e punir pessoas que tenham cometido crimes e, de outro, a garantia do indivíduo de não ser perseguido e punido arbitrariamente.

O direito a um julgamento criminal justo e imparcial é extraído do princípio do devido processo legal, que também está intimamente ligado à proteção do réu contra campanhas da mídia pedindo sua condenação. Este princípio inclui os subprincípios da presunção de inocência, a garantia de 
ser julgado por um juiz imparcial, o direito a que o veredicto seja firmado com base nas evidências introduzidas validamente no processo, etc.

Quanto ao subprincípio da presunção de inocência, que prevê que ninguém será considerado culpado até o trânsito em julgado de sentença penal condenatória, é evidente que ocorrerá sua violação se os órgãos da mídia divulgarem, de forma irresponsável, notícias que já "condenem" socialmente o investigado.

Já em relação ao princípio do juiz imparcial, a preservação da imparcialidade do juiz se faz pela adoção de determinados procedimentos que objetivam neutralizar ou reduzir os voluntarismos, buscando dar ao sistema alguma racionalidade e objetividade. A decisão justa é, portanto, cunhada com o respeito às garantias procedimentais. Assim, são necessárias medidas que garantam, por exemplo, o sigilo das votações, a incomunicabilidade dos jurados e o desaforamento.

A jurisprudência do STF em matéria de desaforamento, por exemplo, evidencia grande sensibilidade em relação aos pleitos formulados pelo Ministério Público, para evitar que os réus detentores de poder econômico, social ou político em pequenas cidades possam influenciar, constranger ou intimidar os jurados locais.

O jurista Leonardo Greco ressalta que:

"A motivação atende a dupla exigência. De um lado, as partes e o público têm o direito de conhecer as razoes que sustentam a decisão e de verificar se essa fundamentação é logicamente consistente e se é capaz de convencê-los de que o juiz empenhou-se para que a decisão fosse a mais acertada e a mais justa possível, de outro lado, o juiz tem o dever de demonstrar que examinou todos os argumentos relevantes de fato e de direito apresentados pelas partes, porque somente assim terão estas a certeza de que o contraditório participativo foi respeitado, ou seja, de que o juiz efetivamente considerou toda a atividade desenvolvida pelas partes para influir na decisão. Não é certo dizer que uma fundamentação racionalmente consistente atente à exigência da motivação. Isso 
não basta. É preciso demonstrar que as alegações, fatos e provas potencialmente relevantes foram examinadas" ${ }^{38}$.

A respeito do direito à publicidade na condução do processo criminal, embora esta seja uma forma de garantir o julgamento justo, tanto em relação às partes quanto em sentido amplo, em relação à sociedade, há a previsão de que o réu, titular do direito de publicidade, pode unilateralmente renunciar a ela pleiteando a decretação do sigilo, para se preservar do constrangimento causado pela exposição de sua imagem, de suposto autor de crime, perante a coletividade.

Sendo assim, o sigilo é necessário, vez ou outra, pois garante ao réu que seus direitos fundamentais não sejam atingidos pela irresponsabilidade da mídia. Ou ainda, quando for necessário à elucidação de fatos em sede de inquérito policial, por exemplo, embora a previsão do Código de Processo Penal, em seu artigo 20 (verbis: a autoridade assegurará no inquérito o sigilo necessário à elucidação do fato ou exigido pela sociedade), não tenha oponibilidade aos advogados.

Neste sentido, a sentença no julgamento criminal, para ser justa, deve ser proferida em um processo guiado pelo princípio do devido processo legal. $\mathrm{O}$ mero desrespeito aos procedimentos revestidos de garantias contidas neste princípio constitucional já ensejaria o questionamento sobre se a sentença condenatória proferida em um ambiente de pressão sobre os juízes é válida e justa.

Desta forma, muitos autores identificam o risco de que campanhas de mídia influenciem indevidamente o desfecho de processos criminais. Apesar de ser o crime um acontecimento público, e a apuração e punição serem de interesse da coletividade, tais premissas não impedem que se investigue a forma como o crime e o criminoso são tratados pelos meios de

\footnotetext{
${ }^{38}$ GRECO, Leonardo. Garantias fundamentais do processo. O processo Justo. In PEIXINHO, Manoel Messias; GUERRA, Isabella Franco; NASCIMENTO FILHO, Firly. Os princípios da Constituição de 1988. Rio de Janeiro: Lumen Juris, 2006, p. 387.
} 
comunicação no Brasil e que se constate que o padrão jornalístico adotado nesse tema pode vir a infringir alguns direitos fundamentais de pessoas que até venham a ser condenadas posteriormente. Até porque a condenação não extingue os direitos fundamentais do réu.

A verdade midiática e a verdade judiciária são formas diversas de lidar com o tempo e a verdade. A verdade midiática deve ser analisada de forma cuidadosa, uma vez que é, às vezes, imprestável para o processo judicial. É que os jornalistas investigativos se valem de métodos que não podem ser utilizados pelos órgãos policiais, dada a impossibilidade de aproveitamento de provas produzidas sem respeito às normas processuais.

Exemplificando, a grande vedete da atividade jornalística de cunho investigativo conduzida pela imprensa é a câmera oculta, seguida do grampo telefônico não autorizado. Mas se essas são consideradas provas ilícitas no processo judicial, sua mera divulgação por influenciar indevidamente o juiz da causa ou fomentar pressão da opinião pública por condenações não suportadas pelo devido processo legal.

O problema de que o juiz se deixe influenciar, conscientemente ou não, pelas evidências não introduzidas validamente no processo, é agravado em processos de júri, pelo simples fato de que os jurados não são obrigados a motivar suas decisões. $\mathrm{O}$ autor Geraldo Prado ressalta, ainda, o fato de os jurados terem contato efêmero com a prova produzida no processo e, "por outro lado, encontrar(em)-se permanentemente sujeito(s) às informações que são incessantemente despejadas pelos meios de comunicação" "39 . Esse acesso desproporcional faz com que suas consciências sejam impregnadas por informações externas e menos sensíveis aos argumentos das partes nos debates travados perante o Tribunal.

\footnotetext{
39 PRADO, Geraldo Luiz Mascarenhas. Opinião Pública e processo penal. Boletim Legislativo Adcoas. Rio de Janeiro, ano 28, n. 30, p. 851-853, out. 1994.
} 
Ana Paula de Barcellos sugere parâmetros gerais de ponderação da liberdade de expressão e do direito ao julgamento justo, quais sejam (i) regras têm preferências sobre princípios; (ii) a norma que de forma direta promova ou proteja direitos fundamentais dos indivíduos (ou a dignidade humana) tem preferência sobre as que estejam apenas indiretamente relacionadas com esses direitos ${ }^{40}$.

Ora, a colisão ora estudada envolve duas norma-princípios, relacionadas a enunciados constitucionais que veiculam regras. A liberdade de expressão é consagrada por norma-princípio, mas seu estatuto constitucional inclui regras, tais como as regras da preservação do sigilo das fontes, da vedação do anonimato, dentre outras.

O direito ao julgamento justo, por sua vez, é extraído do sobreprincípio do devido processo legal, o qual é densificado por subprincípios, como o da presunção de inocência, e regras, como é a vedação da prova ilícita.

Aplicando-se o parâmetro de precedência das regras pode-se concluir que, se alguma regra relacionada com os princípios da liberdade de expressão ou do julgamento justo estiver envolvida na colisão, a prevalência será a favor do princípio amparado pela regra. Citando o exemplo de Simone Schreiber, "se o conflito envolver veiculação na mídia de provas ilícitas, tal elemento jogará a favor do fair trail justificando no caso a imposição de restrição à liberdade de expressão. Ao passo que, se estiver em jogo a regra da preservação do sigilo da fonte, eventual colisão pode ser resolvida a favor da liberdade de expressão"41.

Sucede que, ainda que a liberdade de expressão tenha natureza de direito fundamental e esteja relacionada com a dignidade da pessoa humana, não restam dúvidas de que a garantia de ser julgado sob o devido

${ }^{40}$ BARCELLOS, Ana Paula de. Ponderação, racionalidade e atividade jurisdicional. Rio de Janeiro: Renovar, 2005, p.146 e s.

${ }^{41}$ SCHREIBER, Simone. A publicidade opressiva de Julgamentos Criminais. Rio de Janeiro: Renovar, 2008, p. 381-382. 
processo legal realiza mais diretamente a dignidade da pessoa humana do que a liberdade de expressão. Ou seja, não restringir a campanha da mídia contra o réu, o que reduz suas chances de ter um julgamento justo, viola mais o princípio da dignidade humana do que a restrição fundamentada da manifestação potencialmente prejudicial.

Partindo deste pressuposto, o interesse do público na condução do processo pode perfeitamente ser atendido por uma cobertura jornalística que não se consubstancie em trial by media, que não influencie no julgamento justo do réu.

O juiz, portanto, deve buscar medidas que sejam aptas a promover o fim desejado, que é (i) o de assegurar ao réu que seja julgado sob as garantias do devido processo legal, (ii) o de impor a menor restrição possível ao direito à liberdade de expressão, e (iii) avaliar se o grau de restrição imposto à tal liberdade deve ser justificado em vista da relevância da realização do fim que se busca alcançar, se utilizando do critério da proporcionalidade. 


\section{Capítulo 7.}

\section{Caso Suzane Richthofen}

Um exemplo bastante contundente da consciência de que a Justiça pode ser pautar no clamor público está no julgamento do Habeas Corpus 58813/SP, relatado pelo Ministro Nelson Naves e julgado pela $6 .^{\mathrm{a}}$ Turma do Superior Tribunal de Justiça, em 29 de junho de 2006. A ré Suzane Richthofen e os irmãos Daniel e Cristian Cravinhos estavam sendo julgados pelo homicídio dos pais de Suzane, ocorrido em 31.10.2002.

O caso, de grande repercussão na imprensa, culminou com uma reportagem do programa Fantástico, da rede Globo de Televisão, que veiculou a gravação de imagens captadas furtivamente por um jornalista, mostrando uma conversa entre Suzane e seu advogado, quando este a orientava a chorar na entrevista que daria a seguir. Tal exibição ocorreu em 09.04.2006.

No dia seguinte à exibição Suzane teve sua prisão preventiva decretada sem que nenhum fato novo relacionado com o processo tenha ocorrido - a única causa que poderia ter influenciado na decretação da prisão foi, obviamente, a "farsa" engendrada pela ré e seu advogado, desvendada pelos repórteres, que foi, inclusive, citada na promoção ministerial que postulou a prisão e na decisão do juiz que a decretou, embora tenham sido apontados, ainda, outros fatores, tais como o fato de que a liberdade da ré estaria pondo em risco a vida de seu irmão Andréas, testemunha de acusação no julgamento.

A entrevista de Suzane foi vista como uma tentativa de "criar fatos e situações novas, modificando indevidamente o panorama processual", o que violaria o direito dos jurados de julgar considerando apenas a prova dos autos. Isso num ambiente de campanha midiática pela condenação da ré 
para decretar sua prisão, como se esta não pudesse, legitimamente, quando viesse a ser interrogada no Tribunal de Júri, demonstrar qualquer tipo de emoção, para tentar sensibilizar os jurados.

O acórdão do Tribunal de Justiça de São Paulo, de forma curiosa, atacou os fundamentos da decisão do juiz de primeiro grau, mas manteve a custódia cautelar, mesmo tendo restado evidente que a liberdade da ré não constituía qualquer ameaça à vida de seu irmão. Foi citado, ainda, que a ré “isolou-se com a família que a acolhia, já que rejeitada pela sua, mas não deixou de atender a todo chamamento judicial".

Ao ter a prisão preventiva decretada, a ré apresentou-se voluntariamente ao 89. Distrito Policial do DECAP, em São Paulo, mas, mesmo assim, foi algemada e removida para outra unidade prisional, lá tendo sido mantida "algemada por toda a noite e com as algemas presas a uma corrente, por sua vez presa a uma argola fixada à parede".

Apesar de consignar que o tratamento dispensado à ré pela polícia atendia "apenas à vaidade de alguém, que se aproveitou da voracidade da imprensa para submetê-la a uma remoção desnecessária em meio à multidão hostil, num verdadeiro espetáculo de pirotecnia", e além de ressaltar que o comportamento dos jornalistas que gravaram a conversa entre a ré e seu advogado violava o sigilo advogado-cliente e era anti-ético, o Tribunal considerou que a segurança da ré não poderia ser garantida caso fosse libertada, e que sua fuga poderia ser considerada provável, diante do julgamento que se aproximava, devendo ser mantida a decisão.

O ministro relator do Habeas Corpus no Superior Tribunal de Justiça votou no sentido de conceder a ordem por três fundamentos:

1) O Tribunal já havia revogado prisão preventiva decretada por aquele juiz contra a mesma ré (no HC 41182, de relatoria do Min. Hélio Quália Barbosa, da 6. ${ }^{\circ}$ turma, julgado em 28.06.2005, publicado no 
DJ em 05.09.2005), e a nova ordem de prisão desrespeitava a autoridade do Tribunal;

2) A decisão não foi fundamentada satisfatoriamente;

3) Não havia qualquer requisito que autorizasse a custodia cautelar, não se prestando a isso o clamor público.

Os demais ministros, no entanto, aderiram ao entendimento de Hamilton Carvalhido, que negava a ordem de Habeas Corpus, com voto que se pautava unicamente na recomendação de prestigiar a avaliação feita pelo juiz monocrático dos fundamentos da prisão cautelar. $\mathrm{O}$ Ministro afirmou em seu voto que a decisão poderia "orientar toda a jurisprudência nacional", e que "a publicidade abusiva em torno do caso e a força da comunicação estão a exigir de cada um (...) reflexão maior, mais consciente, mais firme". O ministro Paulo Medina, ademais, alegando agir de acordo com sua consciência, ainda que em detrimento da lei, evidenciou ter cedido à pressão midiática pela denegação da ordem, afirmando, contraditoriamente, que:

"Sabemos que o clamor público não condena ninguém, assim como o clamor público não pode prender ninguém, mas há, também, decisões que estendem que o clamor público, excepcionalmente, pode conduzir à prisão. (...) É por isso que entendo que o clamor público existe; existe sim, existe na vizinhança que não a quer, existe na sociedade que não a quer, existe na instabilidade local que não a quer, existe na comunicação que não a quer, comunicação muito criticada pela defesa, comunicação muito criticada, sutilmente, pelo Ministro-Relator. A comunicação que é indispensável, que não criou o parricídio, não citou a morte da mãe, não criou as entrevistas, comunidade que não criou nada disso. A imprensa, às vezes, estimula, a imprensa, às vezes julga, condena ou absolve. Mas, neste caso, a imprensa nada mais fez senão ecoar a gravidade do crime. A imprensa nada mais fez senão estender a reação à sociedade, a imprensa nada mais fez senão ser a voz do povo que estava a exigir uma reação contra a impunidade. (...) Não que eu defenda em ser servil à sociedade. Não, não sou. Não que eu defenda medo ou temor da imprensa. Não. A imprensa e a sociedade não têm nenhuma influência sobre mim. Mas penso que, agora, elas falam a voz da razão, falam a voz da necessidade de se preservar os aspectos que a garantem, de demonstrar que, aqui e acolá, se exigirá a reação do Poder Judiciário na prestação jurisdicional em nosso País. Denego a ordem de habeas corpus ${ }^{, 42}$.

\footnotetext{
42 Trecho do voto do Ministro Paulo Medina no HC 58813-SP - Relator Nilson Naves - Relator para acórdão Hamilton Carvalhido - Sexta Turma - j. 29.06.2006 - DJ 04.12.2005 - maioria.
} 
Os irmãos Daniel e Cristiano Cravinhos, co-réus no processo, também haviam sido presos devido a uma entrevista dada a um veículo de comunicação, embora tenham havido algumas circunstâncias diversas. Em entrevista concedida à Rádio Jovem Pan os réus confessaram o crime e procuraram justificar a conduta criticando a forma como as vítimas criticavam Suzane, e discorreram sobre seus planos futuros. O juiz de primeiro grau considerou que os réus relataram os fatos com desumanidade e desrespeito às vítimas, fazendo apologia ao crime praticado, além de que o fato citado por Daniel, de que representaria o país em um campeonato de aeromodelismo no exterior, significaria sua intenção de deixar o país.

A prisão também foi pautada na ordem pública, violada pelo episódio. O Superior Tribunal de Justiça apreciou a legalidade da prisão no Habeas Corpus 59674/SP (de relatoria do Ministro Nelson Naves, julgado em 22.08.2006, publicado no DJ em 20.11.2006). O ministro, como no julgamento de Suzane, concedia a ordem, sob os mesmos fundamentos mas terminou vencido pelo voto condutor do Ministro Hamilton Carvalhido, que se limitou a prestigiar a decisão do juiz de primeiro grau.

Em ambos os casos, o fato mais curioso é que a própria ementa do acórdão do HC 59674/SP, por exemplo, consigna que a prisão está baseada na "comoção social" e no "clamor público", provocados pelos crimes e intensificados pelas entrevistas concedidas à imprensa pelos réus:

"Não é ilegal a prisão cautelar, afora por conveniência da instrução criminal e para assegurar a aplicação da lei penal, decretada e mantida para a garantia da ordem pública, por função da intensificação, conseqüente às entrevistas à imprensa, da comoção social e do clamor público provocados pelos gravíssimos e confessados crimes pelos quais já agora estão condenados os paciente e da necessidade de preservar a credibilidade da Justiça" ${ }^{, 43}$.

\footnotetext{
43 Trecho da ementa - HC 59674/SP - Relator Nilson Naves - Relator para acórdão Hamilton Carvalhido - j. 22.08.2006 - DJ. 20.11.2006 - maioria.
} 
O caso citado acima é um pequeno exemplo de como um princípio constitucional garantidor de direitos dos acusados, em ambientes de pressão pública, acaba sendo flexibilizado, até mesmo pelas mais altas Cortes do país, devido à pressão pública, repercutida e fomentada pela imprensa. É notável como o princípio da presunção de inocência pode conflitar com a publicidade opressiva de julgamentos criminais conduzida pela mídia. 


\section{Conclusão}

Com o presente trabalho buscou-se evidenciar a importância de desmitificar o papel que a imprensa se atribui na democracia, como uma instituição descompromissada e despida de interesses que não a fiscalização do Estado, comprometida unicamente com a busca pela verdade. Essa desmistificação não tem como finalidade despir a imprensa de sua importância, especialmente como princípio constitucional; e sim reequilibrar a balança quando tal princípio colide com outros diretos fundamentais.

Além da lesão a direitos da personalidade, as campanhas da mídia contra os acusados em processos penais violam o direito de ser presumido inocente, o que torna provável, a partir da irresponsável divulgação de notícias de caráter meramente sensacionalistas, a repercussão no tratamento dispensado pelos próprios agentes estatais incumbidos da persecução criminal e do julgamento justo da causa. O reconhecimento do clamor público como justificativa para a decretação de medidas cautelares, afrontando a própria legislação processual penal, é um exemplo claro do prejuízo que pode ser causado ao réu.

É necessário haver, portanto, uma reflexão profunda sobre se tal argumento é compatível com um sistema punitivo orientado pelo princípio da presunção de inocência e, como tal, centrado na proteção dos direitos individuais do acusado, que nada mais é do que um cidadão que também deve ser protegido contra eventuais abusos contra ele cometidos.

Uma possível solução é a de que sejam criadas disciplinas jurídicas nas faculdades de Comunicação Social, Jornalismo e diretamente correlatas, de forma a conscientizar os profissionais da área de sua verdadeira função institucional e de que a ética e a responsabilidade em relação ao trabalho são essenciais ao bom funcionamento da Democracia. E com isso, algumas 
noções jurídicas fundamentais seriam transmitidas aos novos e futuros jornalistas.

Da mesma forma, é necessário haver uma maior conscientização por parte dos integrantes do Poder Judiciário, especialmente em relação aos julgamentos de causas de matéria criminal, no sentido de que o acusado merece um tratamento digno e imparcial, despido de influências outras que não o próprio Direito e a Justiça.

Vemos nitidamente que o Judiciário brasileiro, em sua grande parte, não consegue, ainda, tratar da matéria com segurança. A jurisprudência não é consolidada e é comum nos deparamos com situações ambíguas e com julgados que não conseguem desvincular a imagem do acusado do personagem criado pela mídia. Este é mais um motivo que evidencia a importância de termos uma legislação que proteja a sociedade dos abusos que podem ser cometidos contra os cidadãos, motivados unicamente pelos interesses econômicos dos órgãos da mídia, geralmente grandes empresas que detém muito poder econômico.

A efetiva ponderação dos princípios constitucionais é, desta forma, o principal meio de se conseguir uma consolidação da importância do direito a um julgamento criminal justo e de todos os seus subprincípios. As garantias individuais devem ser vistas, inclusive, como um dos pilares da idéia de liberdade de expressão, que deve ter limites para que não ultrapasse sua função institucional, ferindo a sociedade e causando mais prejuízos do que vantagens à sociedade e à própria Democracia. 


\section{Bibliografia}

ANDRADE, Fábio Martins de. Mídia e Poder Judiciário - A Influência dos Órgãos da Mídia no Processo Penal Brasileiro. Rio de Janeiro: Lumen Juris, 2007, 447 p.

BARCELlOS, Ana Paula de. A eficácia jurídica dos princípios constitucionais: o princípio da dignidade da pessoa humana. Rio de Janeiro: Renovar, 2002.

BUCCI, Eugênio. Sobre Ética e Imprensa. São Paulo: Companhia das Letras, 2000.

CERNIVI, Raúl. Revista CEJ. Nuevas Reflexiones sobre Extravictimización Mediática de los Operadores de la Justicia. Brasília, n. o 20, pp. 40-41, dez. 2002.

CLEINMAN, Betch. Litígios de estrondo entre os $3+1$ Poderes da república. Cidadania e Justiça. Rio de Janeiro, ano 3, n. ${ }^{\circ}$ 6, pp. 21-24, 1. ${ }^{\circ}$ semestre 1999.

COIMBRA, Cecília. Operação Rio: o mito das classes perigosas: um estudo sobre a violência urbana, a mídia impressa e os discursos de segurança pública. Rio de Janeiro: Oficina do Autor: Niterói: Intertexto, 2001 .

CORRÊA, Diego Ayres. Os meios de comunicação de massa e sua influência no desenvolvimento da histeria punitiva e na ampliação da repressão penal. Revista de Estudos Criminais. Sapucaia do Sul: Instituto Transdisciplinar de Estudos Criminais - ITEC!, ano 1, n. 3, pp. 96-105, 2001 . 
CRUZ, Patrícia. La Práctica de la ética en los médios de comunicación, p. 2

CRUZ, Rogério Schietti Machado. Publicidade e Sigilo no Processo Moderno. Doutrina. Vol. 9, Rio de Janeiro: Instituto de Direito, pp. 311$323,2000$.

DIMENSTEIN, Gilberto. ILANUD. Crime e TV. São Paulo. Revista n. ${ }^{\circ} 13$. 2001 .

EDITORIAL: Mídia, Imagem e Poder na Democracia. Instituto Brasileiro de Ciências Criminais (IBCCrim), Ano 17, n. ${ }^{2}$ 209, abril 2010, p. 1, Rio de Janeiro.

FERREIRA, Aurélio Buarque de Holanda. Novo Dicionário da Língua Portuguesa. Rio de Janeiro: Nova Fronteira, 2004, p. 1001.

FRANCO, Carlos Alberto di. Imprensa, memória da cidadania. O Globo, Opinião, p.7, Rio de Janeiro, 19.08.2002.

FREITAS, Antonio Francisco de. Análise do discurso jornalístico: Um estudo de caso. Maceió Universidade Federal de Alagoas, 1999, p. 5-11.

GARRIDO, Vicente; STANGELAND, Per; REDONDO, Santiago. Principios de Criminología. $2^{\mathrm{a}}$ Ed., Valencia: Tirant lo Blanch, 2001, p. 871.

GOMES, Luiz Flávio. Mídia e criminalidade. Disponível na internet: www.ibccrim.org.br, 06.07.04.

GRECO, Leonardo. Garantias fundamentais do processo. O processo Justo. In PEIXINHO, Manoel Messias; GUERRA, Isabella Franco; NASCIMENTO FILHO, Firly. Os princípios da Constituição de 1988. Rio de Janeiro: Lumen Juris, 2006, p. 387. 
HABERMAS, Jurgen. Mudança Estrutural na Esfera Pública. Rio de Janeiro: Tempo Brasileiro.1984, pp. 264-265.

HOUAISS, Antônio. Dicionário Houaiss da Língua Portuguesa. Rio de Janeiro: Ed. Objetiva, 2001, p. 2071.

KOSOVSKI, Ester. Ética na Comunicação. Rio de Janeiro: Mauad, 1995, pp. 25-37.

MACCALÓZ, Salete. O Poder Judiciário, os Meios de Comunicação e Opinião Pública. Rio de Janeiro:Lumen Juris, 2002.

MELLO, Silvia Leser de. A cidade, a violência e a mídia. Revista Brasileira de Ciências Criminais. São Paulo: Revista dos Tribunais6, n. 21, pp. 189195, jan.-mar. 1998.

MICHAELIS: Moderno dicionário da língua portuguesa. São Paulo: Cia. Melhoramentos, 1998, p. 1498.

MORETZSOHN, Sylvia; O caso 'Tim Lopes': O mito da 'mídia cidadã', p. 293).

A ética jornalística no mundo ao avesso, pp. 318-

320.

PRADO, Geraldo Luiz Mascarenhas. Opinião Pública e processo penal. Boletim Legislativo Adcoas. Rio de Janeiro, ano 28, n. 30, p. 851-853, out. 1994. Sistema Acusatório.

A conformidade constitucional das leis processuais penais. Rio de Janeiro: Lumen Juris, 1999, p. 179.

RAMONET, Ignacio. A Tirania da comunicação. $2^{\mathrm{a}}$ Ed.. Petrópolis:Vozes, 1999, p. 45. 
ROCHA, Álvaro Filipe Oxley da. Criminologia e mídia: Sistema penal em luta por poder simbólico. In Boletim IBCCRIM. São Paulo: IBCCRIM, ano 18, n. 211, p. 01-02, jul., 2010.

RODRIGUES, J. N. Cunha. Justiça e Comunicação Social: mediação e interação, revista Portuguesa de Ciência Criminal, Coimbra, Coimbra Editora, ano 7, Fascículo 4. ${ }^{\text {o }}$, out.-dez. 1997, pp. 531-576.

RONDELLI, Elizabeth. Mídia e Violência: Ação testemunhal, práticas discursivas, sentidos sociais e alteridade. Comunicação e Política. Rio de Janeiro, vol. 4, n. 3, p. 156, out.-dez. 1997.

SCHREIBER, Simone. A publicidade opressiva de Julgamentos Criminais. 1. ${ }^{a}$ Ed. Rio de Janeiro: Renovar, 2008, p. 91.

SENDEREY, Israel Drapkin. Imprensa e Criminalidade, p. 19.

TEIXEIRA, Sálvio de Figueiredo. A imprensa e o Judiciário. Revista do Instituto de Pesquisas e Estudos - Divisão Jurídica. Bauru: Instituição Toledo de Ensino, n. ${ }^{\circ}$ 15, pp. 15-20, ago.-nov. 1996; Justitia, São Paulo, n. ${ }^{\circ}$ 58 (175), pp. 34-37, jul.-set. 1996.

ZAFFARONI, Eugenio Raúl. Em busca das penas perdidas: A perda da legitimidade do sistema penal. Rio de Janeiro: Revan, 1991, p. 127-128.

www.stj.gov.br

www.stf.gov.br 